\title{
Más allá de la solidaridad revolucionaria. Etnografía y testimonio de una época neoliberal
}

Florencia Mallon. Universidad de Wisconsin, Madison - USA.

Casi treinta años después de que fuera publicada en inglés, la historia de vida de un trabajador de la caña puertorriqueño recopilada por el conocido antropólogo norteamericano Sidney W. Mintz finalmente salió en edición castellana. Poco después de haberse publicado la versión en inglés (1960), recuerda Mintz en su introducción a la nueva edición, «esperaba que se suscitase interés en una edición en español, pero no fue así. Sometí el manuscrito a varias editoriales latinoamericanas, sin éxito, y en Puerto Rico a ninguna editorial le interesaba».(1) Aunque Mintz no lo dice en estas palabras, parece ser que la falta de interés incial en una edición en castellano tenía que ver con que el libro se había adelantado a lo que sería, pocos años más tarde, una tendencia muy marcada hacia el testimonio, o historia de vida, dentro de la antropología. En este género, que se ha vuelto tanto literario como antropológico, se busca rescatar las experiencias de personas «òrdinarias», subalternas en términos sociales o de poder político, personas cuyas condiciones de vida no le permitencomo sí le permiten, y hasta requieren, a miembros de capas sociales más adineradas o con posiciones políticas o intelectuales de prestigio-los espacios de descanso y reflección necesarios para escribir una autobiografia. «Taso es una persona así», nos dice Mintz.

Aunque capaz de leer y escribir y extraordinariamente inteligente - y aunque de hecho escribió dos segmentos de su propia historia-no creo que hubiese intentado divulgar la historia de su vida, ni en palabras ni de ninguna otra forma, sin invitación. Quizás debo señalar que este hombre, 'Taso' Zayas, no es ni una figura pública, ni un hombre famoso, ni prestigioso, ni distinguido. De hecho, aparte de su inteligencia extraordinaria, se podría describir a Taso como un hombre promedio en casi todos los sentidos. Lo que sigue, entonces, es la autobiografía de un hombre promedio. Pero traté de dejar claro cuando escribí el libro que esto no quiere decir, definitivamente, que Taso sea 'típico', representativo de otros, ni ordinario...(2)
¿Qué pasó, entonces, entre 1960, cuando la historia de vida de don Taso Zayas apareció en inglés por primera vez, y 1988, cuando salió la edición en castellano, suscitanto renovado interés en los ámbitos de habla española? La respuesta simple a esta pregunta tendría que ser el boom de la literatura de testimonio. Y este boom, creo yo, ha tenido dos orígenes que, aunque interrelacionados, vale la pena separar por razones analíticas. Primero, la evolución de una categoría literaria llamada testimonio fué aprobada formalmente cuando la Casa de las Américas en La Habana, Cuba inició su Premio Testimonio en 1970. Esto vino a culminar la popularidad creciente de este tipo de trabajo, representado quizá más dramáticamente por el libro del antropólogo cubano Miguel Barnet, Biografia de un cimarrón (1966). En parte, esta tendencia representaba el creciente entusiasmo por las vidas y los heroísmos populares que había suscitado la revolución cubana de 1959 y la creciente radicalización a nivel mundial de la década de los 60 . Pero se vino a mezclar también con una crisis intelectual y metodológica suscitada al interior de la antropología a comienzos de los años 80 .

La crisis en la antropología tuvo como base un doble cuestionamiento. Por un lado, se empezó a cuestionar el discurso científico con el cual se justificaba el trabajo de campo, dentro del cual la relación entre antropólogo e informante sería nada más que un medio a través del cual se conseguían datos culturales generalizables y comparables a nivel general. Ya en abril de 1984, un grupo de antropólogos ingleses y norteamericanos se reunieron en Nuevo México en un seminario sobre la etnografía cuyos resultados, publicados dos años más tarde, sirvieron para cristalizar una serie de críticas acerca del barniz científico que revestía su profesión, reivindicando la experiencia personal, la técnica literaria y hasta el contenido poético de «escribir la cultura». Por otro lado, también se empezó a debatir más abiertamente lo que Mintz llama una tendencia «a trivializar las grandes diferencias en riqueza, oportunidad y poder que separaban al académico del informan-

1) Sidney W. Mintz, Taso: trabajador de la caña con estudio preliminar, bibliografia y cronologia de Francisco A. Scarano (Rio Pledras, P.R.: Ediciones Huracán, 1988 ), p.60.

2)Ibidem, p. 61 . 
te, y a convertir en objetos a aquéllos de quienes los antropólogos tenían que depender para recoger información’.(3) Una de las direcciones en la cual esta crisis llevó a la antropología fué a un encuentro con la literatura, y especialmente con las técnicas y los debates literarios en que se estaban tratando de romper los cánones más clásicos y por tanto constringidos de la academia. En ambas disciplinas, hubo una atracción hacia las transgresiones al método científico y objetivista representadas por el postmodernismo o postestructuralismo.

Estas influencias ya se vislumbraban en los trabajos de los antropólogos del seminario de Nuevo México y uno de ellos, Stephen Tyler, hizo un llamado a la creación de una etnografía postmoderna, definida como una etnografía que enfatiza el diálogo en vez del monólogo, que enfatiza la naturaleza cooperativa y colaborativa de la situación etnográfica en contraste con la ideología del observador trascendental. De hecho, rechaza la ideología del «observador y el observado», puesto que no hay nada que observar y nadie que es el observador. Hay en cambio una producción mútua, conversada, de un discurso o una suerte de cuento o historia.(4)

La verdad es que el texto de Mintz y Zayas, aunque producido veinte años antes, ya era una respuesta importante a este llamado. Mintz no solamente integró al libro las entrevistas que hizo con doña Elí Villaronga, esposa de Zayas, sino que también dejó sus preguntas en el texto, estableciendo un estilo de conversación e intercambio. Intercaló además los fragmentos escritos por don Taso con sus propias reflecciones más «académicas». En sus introducciones a ambas ediciones explica detalladamente su método de recopilación del material, y también el proceso de organización y reorganización de éste en el proceso de crear un libro. En este sentido, por lo menos, el texto original de Mintz era un libro que se adelantó a su tiempo. Pero en otro sentido también, hasta cierto punto irónicamente, el libro de Mintz estuvo todavía más adelantado a su tiempo, puesto que yo creo que nos ayuda a encontrar una solución a una nueva crisis que se va creando en el campo de estudios culturales por el excesivo uso de supuestos y técnicas postmodernistas para pensar el género de testimonio, cortándole las conecciones que tiene y debe tener con el trabajo etnográfico.(5)

Uno de los debates más apasionados que se ha dado recientemente en el campo interdisciplinario de los esturdios culturales es sobre la capacidad de habla o expresión que tendría el sujeto subalterno, y por tanto sobre la legitimidad o viabilidad de cualquier intento de representar las voces subalternas en los textos escritos. A pesar de que los métodos postmodernos fueron inicialmente atractivos por su capacidad de criticar los métodos y cánones establecidos dentro del mundo académico, y por tanto reivindicar la importancia de las experiencias y perspectivas marginales a dicho mundo, el mismo marco teórico dentro del cual operaban estos métodos le negaban voz y existencia a los sujetos o culturas periféricas a los centros de poder. Según el crítico literario George Yúdice, «la tarea de los deconstruccionistas no ha sido vindicar o emancipar a los elementos marginales, sino detectar las marcas que dejan al ser consumidos por las proyecciones intelectuales de la racionalidad o la lógica del centro»s. En este contexto, concluye Yúdice, los grupos marginalizados, el «otro», «no existe más que como la ausencia establecida por el proceso de diferenciación».(6)

Frente a esta situación algunos academicos influenciados por el postmodernismo, como Yúdice mismo y también John Beverley, vieron en el género testimonio una posible salida a este problema, puesto que permitía la reivindicación de la presencia del otro y por tanto criticaba a los supuestos teóricos excluyentes del nuevo canon. Esto sería posible, según estos estudiosos, porque el testimonio latinoamericano estaba inbricado dentro del tejido popular de movimientos guerrilleros o de resistencia al autoritarismo. En tal situación la necesaria mediación de un intelectual foráneo, quien grababa y organizaba la narrativa, se volvía un

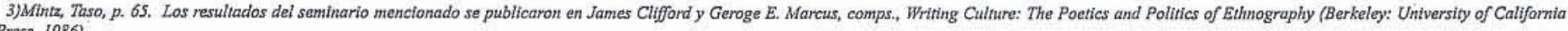
Press, 1986).

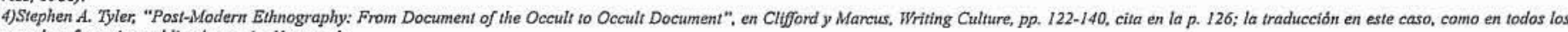
casos de referencias publicadas en inglés, es mia.

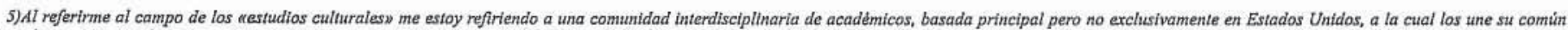

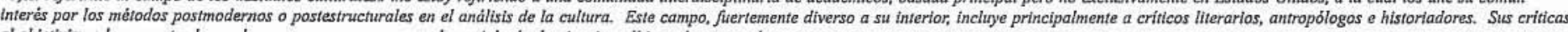
al objetivismo han penetrado mucho menos en campos como la sociologia, la ciencia politica y la economía.

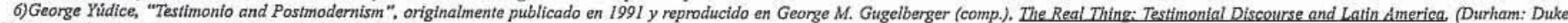
University Press, 1996), pp. 42-57; citas en las pp. 49 y 50.
} 
acto de solidaridad revolucionaria en vez de un acto de canibalismo cultural. Conceptualizado por Beverley, el testimonio como género literario daba voz a «un sujeto colectivo, popular-democrático, al pueblo», por tanto resolviendo, a través de la solidaridad, las «contradicciones profundas e inescapables» entre el sujeto/narrador y el editor. Esta solidaridad Beverley la definía como «un sentido de mútua hermandad en una lucha contra un mismo sistema de opresiónł.(7)

Pero, ¿qué pasa hoy, en nuestro mundo postrevolucionario y neoliberal, cuando las luchas de liberación han sido derrotadas o, en el mejor de los casos, marginalizadas? Los mismos académicos que antes celebraron el poder de transgresión del género testimonio han repensado sus posiciones anteriores. Como antes, es Jobn Beverley el que resume más nítidamente la nueva problemática al sugerir que el momento histórico del testimonio, que le dió su particular urgencia, ya ha pasado. El testimonio inició su popularidad con el momento revolucionario de los años 60 , anota Beverley, y culminó como una forma de denuncia durante la represión y el autoritarismo de los años 70 y 80 . «Era lo Real, la voz del cuerpo que sufría, de los desaparecidos, de los perdedores en la carrera hacia el mercado»y. También sirvió de corrector dentro del campo literario al demostrar que los escritores del boom latinoamericano no eran las únicas voces legítimas del pueblo latinoamericano. Y finalmente, el testimonio nos dió una alternativa popular, surgida de los movimientos sociales y de solidaridad, a los supuestos vanguardistas de la política partidaria.

Al finalizar el siglo XX, sin embargo, Beverley concluye que el género de testimonio «se ha separado de estos contextos» y por tanto ha perdido «su poder especial tanto estético como ideológico». En parte ésto ha pasado porque el testimonio ha sido incorporado, cada vez más, a los discursos literarios puramente académicos y por tanto ha perdido su legitimidad original y su capacidad de transgresión. Se agrega a ésto, según Javier Sanjinés, que las fuerzas del mercado y de la globalización han destruído las condiciones materiales y políticas que antes facilitaban la formación de los movimientos sociales y de los sueños utópicos que ayu- dáron a nutrir el testimonio. ¿Qué nos queda, por tanto? «¿Qué nos queda hoy»-pregunta Beverley-»del deseo llamado testimonio?» Y su respuesta es: «Chiapas».(8)

Seguir creando relaciones de solidaridad revolucionaria en Chiapas, y por tanto producir más textos dentro del género testimonio-denuncia, es legítimo y crucial. Pero yo quisiera sugerir que también existe un camino alternativo para enfrentarse a los cambios intelectuales y políticos tan profundos que se han suscitado en nuestro mundo con la caída del muro de Berlín. Estos cambios han significado, por un lado, la multiplicación de estados de emergencia, a nivel de los derechos humanos y las condiciones de vida de la gente del llamado Tercer Mundo; y por tanto es importante continuar nuestras prácticas de solidaridad y denunicia para salvar vidas y condenar abusos. Por otro lado, la misma multiplicación de emergencias tiende a hacer menos sensibles las conciencias internacionales y por tanto dificultar la expansión de la solidaridad; al mismo tiempo, una mentalidad de emergencia tiende a crear una situación en que la atención mundial salta de caso a caso, sin enfocar lo que pasa en un lugar cuando ya ha terminado la crisis motivo de la atención. ¿Debemos también encontrar formas de narrar y analizar los problemas quizá un poco menos dramáticos que quedan después que termina la guerra o la dictatura, como son la pobreza, subordinación, exclusión política, desnutrición, discriminación cultural? Aquí creo que el trabajo de Mintz con Zayas nos da algunas pautas importantes.

La relación entre Mintz y Zayas que produjo el testimonio Taso se estableció en un momento de fuerte tendencia conservadora en Estados Unidos, cuando la Guerra Fría y el macartismo había impactado fuertemente a la generación intelectual de izquierda a la que Mintz pertenecía. Don Taso Zayas era un activista sindical e izquierdista que sufrió los golpes del caudillismo político y la corrupción, y que finalmente encontró algún consuelo y un nuevo sentido a su vida en la religión pentecostal. Para Mintz fué casi imposible comprender la atracción que sentía alguien como Zayas - a quien veía como un hombre excepcionalmente inteligente y racional-a una religión carismática. El testimonio pro-

7)John Beverley, "The Margin at the Center: On Testimonio (Testimonial Narrative)», originalmente publicado en I989, reproducido en Gugelberger (comp.), The Real Thine pp. 23-41, citas en pp. 31 y 33.

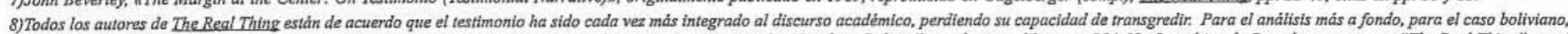

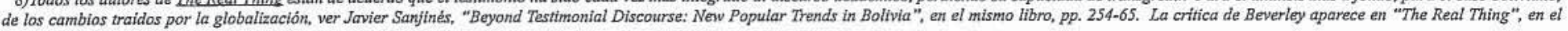
mismo libro, pp. 266-86, citas en pp. 281-82. 
ducido es en parte un argumento entre los dos acerca de esta conversión. Este testimonio también surge de una relación etnográfica más amplia con el barrio donde viviera Zayas, puesto que Mintz hace primero un estudio de comunidad y vuelve luego para profundizar su amistad con don Taso, una amistad que ha durado toda una vida. Por una parte, Mintz está conciente, a un nivel bastante profundo, de las diferencias que lo separan de.su amigo puertorriqueño. Durante su primera visita de retorno, recuerda en su introducción a la versión castellana, se sintió culpable al escucharlo decir a Zayas, «Te echo de menos. Echo de menos nuestro trabajo juntos. Ahora que la casita detrás de la nuestra está vacía, recuerdo nuestro trabajo». Esta imagen inspira en Mintz una reflección más amplia:

He ahí la desigualdad, la asimetría tan importante en la relación entre antropólogo e informante, en contraposición a la desigualdad, la asimetría importante entre metrópoli y colonia. Yo continuaba gozando de la libertad para asociarme con otros como yo, por puro placer; de la libertad para enseñar y pensar y leer y escribir para ganarme la vida. Mi amigo, mi igual en todo sentido-créo que de manera muy important, claramente mi superior-continuaba trabajando con sus manos, en labores terriblemente duras, durante horas demasiado largas, por muy poca paga.(9)

Por otra parte acepta el reto, el desafío, de mediar contradictoria e imperfectamente el relato de Taso Zayas. Esta aceptación se legitima, no en una colaboración de solidaridad revolucionaria, sino que en una amistad larga y profunda aunque desigual, una amistad que comenzó con un detallado trabajo etnográfico que ayudó a crear conecciones humanas. «La historia de Taso no tiene moraleja,» concluye Mintz la edición inglesa.

Quizás baste con que su vida le parezca mucho mejor ahora que antes. O quizás el lector vea el desperdicio que yo creo ver: el desperdicio de una mente que sobresale de las otras como las guajanas sobresalen de la caña. Pero la historia no debe provocar lástima, porque ese sentimiento degrada el sentido de la vida de Taso, para él, y para los que lo conocen y lo aman.
Y agrega en un post scriptum a la versión castellana:

A los que deciden ver en él algún tipo de rendición ante las circunstancias, nada de lo que yo pueda decir—o de lo que Taso pueda decir—cambiará su punto de vista. Pero para los que comprenden cuán complejos son los modos en los que los seres humanos triunfan sobre las limitaciones en contra de las que deben luchar, la vida de Taso seguirá siendo una fuente de inspiración.(10)

Es aquí que podemos encontrar, a mi entender, los comienzos de un nuevo tipo de testimonio, basado en las relaciones profundas pero también concientes facilitadas por el trabajo etnográfico. Una articulación creativa, aunque siempre conflictiva, entre etnografía y testimonio, historia de vida y trabajo en terreno, nos sugiere otro camino que nos pueda llevar más allá de la crisis del testimonio como denuncia. Sin reconstruir las viejas ilusiones de objetividad científica, aceptando el reto y la responsabilidad de una etnografia postmoderna en cuanto diálogo y conversación, podemos abrir nuevas posibilidades a través de las cuales podemos seguir narrando, a fondo y en formas nuevas, la complejidad de «los modos en los que los seres humanos triunfan sobre las limitaciones en contra de las que deben luchar».

En el resto de este ensayo quisiera explorar algunas de estas posibilidades a través de una discusión de mi experiencia de trabajo etnográfico y archivístico en Chile entre 1996 y 1997. Cuando en 1990, después de una lucha dramática de casi diez años en contra de la dictadura pinochetista, el pueblo chileno reestableció un régimen democrático en 1990 con la elección de Patricio Aylwin, los activistas extranjeros de derechos humanos, los observadores políticos y hasta algunas platas internacionales de las ONG's emprendieron su retirada. En una situación en que los observadores internacionales, las fundaciones y entidades de financiamiento pronunciaron a Chile transformado y en buena salud democrática, los activistas locales de toda una variedad de movimientos sociales se quedaron solos tratando de dar sentido a sus experiencias de movilización

9) Mintz, Tase p. 66.

10) Mintz, Tase pp. 314 y 315. 
antidictatorial dentro de un nuevo clima de modernización, crecimiento económico, e impunidad. Poco a poco cayó sobre muchos de ellos un velo de depresión posttransicional: la tan anhelada, tan alabada y celebrada democracia no resultó llenar todas las expectativas. La comunidad internacional, tan presente en épocas de lucha y transición, se hizo sorda frente a las profundas reflècciones y a los intentos de innovación política con que algunos trataron de paliar sus anhelos por una democracia que nunca podría regresar igual. Ironicamente, en algunos casos se llegó hasta a tener nostalgia por las formas de unidad y solidaridad que habrían sido posibles en dictadura.

Esta era la situación a la cual llegué en 1996, mucho después de que el «taco» de solidaridad y testimonio se había desplazado - hacia el norte, como observa Beverley, a Chiapas. Fué en este contexto que empecé a desarrollar relaciones cercanas, en la región de Temuco, con activistas y comunidades Mapuches. A pesar de que mi intento de narrar estas experiencias pasa, necesariamente, por teorías y textos académicos, las amistades que formé no son ni teóricas y textuales. Por tanto, organizaré mis reflecciones en torno a cuatro casos concretos en que mis relaciones con las comunidades, las familias y los individuos generaron desafios particulares a los que todavía me estoy enfrentando. De estos cuatro casos, uno se trata del género testimonio y de mi amistad con una intellectual Mapuche activista y feminista. Los otros tres casos involucran mi relación con una comunidad, y con la familia extendida de Ailío que forma su tronco principal. Al enfocar mis reflecciones en estos casos concretos, y en los desafíos que han presentado para mi y para la gente a quien empiezo a conocer bien, mi propósito es iniciar una conversación acerca del pasado, el presente y el futuro que nos ayude a pensar alternativas para enfrentarnos a la realidad global y neoliberal en la cual vivimos.

Forjando testimonio: Isolde Reuque, la familia Reuque Paillalef y yo.

Conocí a Isolde Reuque Paillalef el 29 de noviembre de 1996. Habíamos hablado por.teléfono un par de veces, preparando nuestro encuentro, y había escuchado de mi colega santiaguina María Elena Valenzuela un resumen del papel de Isolde como dirigente feminista Mapuche, resumen que incluía una descripción de cómo María Elena había llegado a conocer a Isolde como parte de la delegación chilena al Congreso Internacional de la Mujer en Beijing el año anterior. Con Isolde nos encontramos en el Café Raíces, ese experimento unitario y demasiado corto que, durante unos ocho meses en el centro de Temuco, logró integrar una serie de culturas, músicas, joyas y comidas indígenas de diferentes partes de América Latina. No lo sabíamos en ese momento, pero al Café Raíces ya le quedaba poco tiempo antes de que tuviera que cerrar sus puertas. Y aunque no comprendí la importancia simbólica de la coincidencia, nos conocimos por primera vez la tarde del mismo día en que me había encontrado, también por primera vez, con los dirigentes de Nicolás Ailío, comunidad Mapuche que se tranformaría en el otro caso «profundo» de mi trabajo etnográfico de los próximos seis meses.

Lo que sí tenía perfectamente claro en ese momento era el motivo de mi interés en una conección con Isolde Reuque. Hacía menos de un año, yo había enseñado un curso en mi universidad sobre el testimonio y la historia oral, donde habíamos leído los experimentos más recientes con el género de testimonio además de repasar algunos de los textos clásicos. También habíamos discutido algunas de las opiniones sobre el testimonio como género que estaban escribiendo los críticos literarios postmodernistas y feministas. En tal contexto, una de mis metas era explorar la posibilidad de colaborar con una mujer Mapuche en la producción de un testimonio feminista. Estaba buscando una relación horizontal o egalitaria, en lo posible. No me interesaba contar la historia de una «típica campesina», y la categoría misma me parecía difícil de definir. Quería colaborar en un testimonio cuyo narrador/sujeto podría dialogar y refleccionar conmigo sobre las complejidades políticas y culturales de su pueblo.

Por lo que ya sabía antes de nuestra primera conversación, Isolde Reuque bien podría ser exactamente la persona que yo buscaba. Ya me había entrevistado con otra dirigente e intelectual Mapuche, persona que trabajaba en CONADI, y nos habíamos llevado muy bien. Pero por una serie de razones, la más importante de las cuales era que siempre andaba demasiado ocupada en su puesto, no habíamos logrado concertar otra cita después de varios intentos. La otra dirigente con que me había entrevistado era, además, una mujer eminentemente urbana, con experiencia urbana. A pesar de la gran importancia de la tradición urbana dentro de la cultura Mapuche, con lo poco que yo sabía en noviembre de 
1996 ya había encontrado en las fuentes primarias y secundarias que desde los comienzos del siglo XX se había empezado a vislumbrar una separación entre lo urbano y lo rural en las organizaciones políticas e intelectuales del pueblo Mapuche.(11) Solamente en la generación contemporánea, de la cual formaban parte ambas mujeres, se había empezado a reivindicar en forma mayoritaria, desde lo urbano, al importancia de las tradiciones rurales. Pero de todas maneras me interesaba poder conocer la experiencia de una intelectual y dirigente que había comenzado desde el campo. En mis conversaciones con mi colega María Elena en Santiago, ella me había enfatizado que Isolde Reuque había crecido en una comunidad rural.

Con Isolde nos llevamos muy bien. Era honesta, intelectualmente muy aguda; tenía confianza en si misma y sentido de humor. Un mes más tarde, cuando lé́ la desgrabación de nuestra primera entrevista al preparar mi siguiente viaje a Temuco, me percaté de varios momentos en que yo había intentado demostrarle lo mucho que ya sabía, como reacción a mis propias inseguridades de wingka y semi-gringa. Pero ella tuvo muchísima paciencia conmigo, y no se dejó irritar por mi ignorancia y mis poses, aún cuanto interrumpí una importante discusión para mostrarle lo mucho que yo sabía. En realidad nos llevamos tan bien que en algún momento durante esa primera conversación puse mis cartas intelectuales sobre la mesa. Me acuerdo haberle dicho (aunque ésto no quedó grabado en la cinta) que me gustaría explorar la posibilidad de que colaboráramos en escribir su testimonio o historia de vida. Le propuse las siguientes condiciones. Primero, que ella sería la autora principal, y su nombre aparecería primero en la portada del libro y que mi nombre aparecería más abajo, «con Florencia Mallon». Segundo, que ella recibiría desgrabaciones de todas las conversaciones y tendría la última palabra en cuanto a la versión que se publicaría. Tercero, que yo me encargaría de las desgrabaciones y de organizar el texto con algún orden narrativo inicial, aunque ella después tendría la última palabra sobre las revisiones. Cuarto, que ella y yo tendríamos la oportunidad de escribir, cada una, nuestras propias introducciones y conclusiones. Y finalmente, que todo ésto significaría bastante trabajo de nuestra parte durante los próximos seis meses.
Ella expresó su interés inmediatamente y acordamos reunirnos nuevamente la próxima semana, antes de que yo viajara a Santiago.

Cuando yo le propuse a Isolde las condiciones de nuestra colaboración, me había inspirado en un reciente libro de testimonio, la colaboración entre Lynn Stephen, antropóloga norteamericana, y María Teresa Tula, activista salvadoreña de derechos humanos y miembro del Comité de Madres y Familiares de Presos Políticos, Desaparecidos y Asesinados de El Salvador (CO-MADRES). Entre todos los libros de testimonio que yo había leído, esta historia de la vida de Tula era el que más me había inspirado a pensar el testimonio como colaboración horizontal.(12) Tardaría más en comprender realmente, desde el punto de vista de Isolde, cuáles eran los puntos más atractivos de mi oferta. Me acuerdo que en un primer momento mencionó que era algo que ya lo había estado pensando, pero que nunca lograba encontrar el tiempo, dentro de las rutinas de su vida, para sentarse frente a su computador a escribir. Y me invitó a su casa en el sector Pedro de Valdivia de Temuco, una estructura de dos pisos que ella había estado construyendo con su marido, pedazo por pedazo, desde su matrimonio algunos años atrás.

Llegué a su casa el 3 de diciembre de 1996, como a la hora del té. Caminé las tres cuadras de camino sin pavimentar desde la parada de autos, casi tambaleando bajo el peso de una mochila llena de notas y fotocopias tomadas durante mi día de investigación, de alguna manera cargando también mi computador portátil. En preparación para nuestra conversación había pasado por el mercado a comprar una bolsa de yerba mate, aguantándole a la dueña del puesto su mirada de sorprendida curiosidad al ver a esta gringa wingka comprando yerba. Ya sabía, gracias a conversaciones y experiencias previas, que traer yerba señalaba mi disposición a sentarme un rato, «pelar» un matecito y dejar que la conversación tomara su propio curso. Ya había escuchado varias veces la cinta de nuestra primera conversación y me había preparado con una serie de preguntas acerca del movimiento Mapuche entre 1978 y 1995, queriendo profundizar sobre su papel político en esos años y también sobre su análisis de los cambios que se habían dado. Hablamos por más de tres horas, y a veces se nos

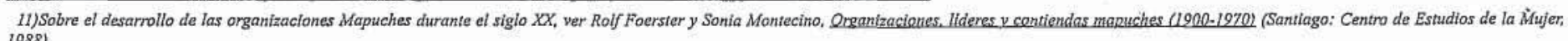
1988).

12)Lynn Stephen (comp.), Hear My Testimonv: Maria Tenesa Tula. Human Rights Activist of El Salyader (Boston: South End Press, 1994). 
unieron su marido y una de sus hermanas. Isolde se abrió sobre sus frustraciones frente al movimiento Mapuche, y empecé a tener más claras las complejidades de su papel y el de otros dirigentes.

Mi próxima visita a Temuco fué en el mes de enero de 1997, que lo pasé entero en la región haciendo investigación en los archivos y saliendo a terreno. Yo estaba muy ocupada, en parte porque me acompaño mi hijo de quince años, en vacaciones escolares; pero Isolde lo estaba más. Durante el mes entero logramos una sola conversación de media hora. Cuando visité su casa para entregarle sus copias de las desgrabaciones de nuestras entrevistas, se las tuve que dejar al vecino. Empecé a comprender porqué me había dicho, en nuestra primera entrevista, que nunca podía encontrar el tiempo para sentarse a escribir. De hecho, me empezaron a surgir dudas sobre la viabilidad de nuestro plan de colaboración. Del lado positivo, sin embargo, un mes completo pasado en los archivos de Temuco, combinado con un trabajo intenso en terreno con la gente de la comunidad de Ailío, me ayudó a llegar a la cima de mi primera montaña conceptual. Por primera vez sentí que tenía una visión clara de mi proyecto en su conjunto, y que vislumbraba sin dificultad el camino a seguir.

El mes de febrero fué un mes de vacaciones y obligaciones familiares, así que cuando regresé a Temuco a mediados de marzo fué con una nueva y fresca determinación de avanzar rápidamente en las conversaciones con Isolde. Desde nuestra primera conversación, cuando me había contado algo sobre su comunidad, me había surgido el deseo de visitar Chanco con ella y conocer a su familia y sus vecinos, posiblemente investigar un poco la historia de la comunidad. Cuando se lo había propuesto anteriormente, siempre había demostrado interés pero nunca logramos concretar fechas. E1 14 de marzo, recién llegada de Santiago, la llamé por teléfono e inmediatamente propuse una visita a Chanco. Esta vez concretamos para ese mismo fin de semana, en domingo puesto que el sábado ya tenía programada una visita con la gente de Ailío a las nuevas tierras que habían comprado con el subsidio de la CONADI. El domingo, con la ayuda de Isolde, llené varias bolsas de supermercado para llevar de regalo, las que presentamos inmediatamente a su madre al bajarnos de la micro y subir el cerro. Pasamos la tarde entre conversación, comida y mate, con sus padres, su hermana y su hija.
Logré entrevistar brevemente a su padre, don Ernesto Reuque, longko de la comunidad. Elvira, hermana menor de Isolde, me presentó a varios de los jóvenes que conformaban el grupo juvenil de la comunidad y me mostró la biblioteca que estaban armando para ayudar a los escolares con sus tareas.

La primera visita a la familia y la comunidad nos resultó bastante bien, y creo que nos ayudó a establecer el tono para nuestra próxima entrevista en Temuco el siguiente miércoles. Acompañada de su hermana Elvira, Isolde se tornó más reflexiva e íntima. Las dos compartieron experiencias de lo que significaba ser mujer en la cultura Mapuche, las dificultades que habían tenido estableciendo una relación romántica con un compañero, y hasta las razones por las cuales Isolde se sentía tan cómoda en su relación con sus suegros. Había algo en la dinámica de esa conversación, que incluyó además un recuento de los altibajos que Isolde había experimentado, años atrás, como madre demasiado joven, que me convenció que habíamos llegado a un nuevo nivel. Las tres también trabajamos un posible esquema para el libro y empezamos a discutir posibles títulos.

Llamé otra vez en abril, al regresar a Temuco, y supe que se había desarrollado una pequeña crisis. Uno de los ancianos de la comunidad, con quien habíamos hablado la vez anterior para concertar una entrevista en mi próxima visita, había decidido exigir que se le pagara, y habia citado una cifra bastante alta. Isolde le había contestado que eso no era posible, y que tendríamos que entrevistar a otras personas. A ambas nos causo cierta frustración este incidente, e Isolde me contó que también su madre se había sentido enojada, pero decidimos viajar a Chanco de todas maneras. Solamente más tarde estuve conciente de dos subtextos que habían emergido de esta situación. El primero era que la familia de Isolde ya sentía un sentimiento protector hacia mi, tomando mi parte al surgir un désacuerdo con sus vecinos sobre lo que yo estaba haciendo en la comunidad. El otro se relacionaba con lo complicado de la colaboración con gente de fuera. Por una parte, el anciano legitimamente estaba pidiendo reciprocidad en la relación con una investigadora no Mapuche; pero por otra, al exigir dinero, rompió la conección conmigo y al mismo tiempo hizo que Isolde se sintiera extraña, fuera de comunicación con gente de su propia cultura y comunidad. 
Viajamos a Chanco el sábado 19 de abril, pensando regresar al día siguiente. Nos alojaríamos con su familia y tendríamos bastante tiempo para conversar con otra gente de la comunidad y también seguir nuestro propio diálogo. Dicho y hecho, aunque cuando llegamos a la casa familiar, después de los saludos, conversaciones iniciales y el inevitable matecito, Isolde nos. informó que tendría que regresar esa noche a Temuco a una reunión-política. Yo me podía quedar la noche, insistió, y seguiríamos nuestras conversaciones al día siguiente cuando ella regresara. Cuando le respondí, un poco decepcionada, que este no era el plan que habíamos acordado, y le pregunté porqué no me había informado del cạmbio antes de que saliéramos de Temuco, Isolde se rió y me dijo algo parecido a, bueno, pero ¿porque no tomarlo como una rara oportunidad? ¡Puedes hablarle a mi familia, hasta pelarme, sin que yo esté presente!

No la pelamos, pero si hablamos muchísimo con su madre doña Martina Paillalef, su hermana Elvira, su hija Liliana y Lionel, su hermano mayor. Por casi dos horas, llenando casi dos casettes y tomando mate y vino, discutimos temas tan diversos como el mito de origen del linaje Paillalef (Lionel lo había leído en un libro), la infancia de doña Martina, la experiencia de ir al colegio como niños Mapuches, los altibajos de la Ley Indígena y de la transición a la democracia, las complejidades de cualquier intento de preservación cultural entre poblaciones minoritarias. Terminamos riendo y tomándonos el pelo mutuamente, y Lionel me amenazó con robarme un cortaplumas mío con el cual se había encariñado (antes de irme de Chile se lo dejé de regalo, y al regresar a Temuco en agosto de 1998 los pienso visitar a los dos). Cuando Isolde regresó a la mañana siguiente el reportaje sobre nuestra conversación fué positivo y las dos encontramos un lugar relativamente apartado donde pudimos seguir con nuestras entrevistas. Ese día llenamos cuatro casettes con una serie de reflecciones acerca de los eventos y puntos cruciales del movimiento Mapuche, inspiradas por mis investigaciones previas en los periódicos de la época. También me hizo sugerencias acerca de cuáles diarios y fechas adicionales yo debería buscar al regresar a la hemeroteca en Santiago. En algún momento también decidimos que íbamos a incluir en el libro la conversación que yo había tenido con su familia.
Las entrevistas de abril marcaron un hito en nuestro proyecto. Aunque siempre nos fué dificil saber çuánto camino habíamos recorrido (hasta que, en una noche de mayo, sentadas en la cocina de su casa en Temuco, de repente supimos que habíamos terminado), en abril las dos estábamos seguras que habíamos avanzado más allá de la mitad. En mi computador compusimos un borrador del esquema final del libro que sería nuestro mapa durante todas nuestras entrevistas de mayo. Pero el hito se trataba de más que el simple volumen de las entrevistas ya grabadas; también tenía que ver con la confianza. En la micro volviendo a Temuco esa misma noche, Isolde me confesó que, aunque había colaborado en varios proyectos de investigación anteriores, nunca se habían tratado de su propia comunidad. Hasta entonces, había trazado una línea firme entre traer a sus amigos a Chanco a conocer a su familia, y acompañar a investigadores a otras comunidades, especialmente a la comunidad de su marido. El abrirme paso en su comunidad y su familia había sido, al mismo tiempo, una prueba y una señal de confianza inicial; felizmente yo había logrado conseguir su aprobación. En junio, cuando tuvimos un seminario sobre mi investigación al cual vinieron representantes de varias de las comunidades mapuches donde yo había trabajado, se les preguntó a los presentes qué era lo que habían conseguido al colaborar conmigo. Isolde respondió con afecto y humor que había aprendido cosas acerca de su comunidad que nunca antes había sabido, no solamente al acompañarme en mis entrevistas con algunos de los ancianos, sino que también (y aquí no pudo resistir una pequeña risa) en las conversaciones que tuvieron después de que yo me iba.

Durante el año que llevo fuera de Chile, durante el cual he terminado de organizar un borrador incial del libro testimonio producto de nuestras conversaciones, he refleccionado muchas veces acerca de la amistad que hemos desarrollado con Isolde. Por un lado, he meditado bastante sobre las diferencias-de experiencia de vida; de cultura; de posición, título y conecciones profesionales; de privilegio económico; de país de residencia con todo lo que eso conlleva. He pensado también que el balance de fuerzas entre las dos está en proceso de cambio con el tiempo. Si empezamos de una situación inicial en la que yo dependía muchísimo más de ella, confiando en que me enseñaría acerca del pueblo 
y la experiencia mapuches, que me llevaría a su comunidad y me ayudaría a comprender, hemos llegado a una situación en la cual yo he elaborado un borrador basado en su testimonio y, aunque ella tenga la autoría, derechos de autor y derecho de revisión final, yo tengo los contactos de publicación, no solamente en Chile sino que también en Estados Unidos. En este sentido su deseo, su necesidad de divulgar su punto de vista sobre las experiencias conflictivas e inspiradas, felices y dolorosas, del movimiento mapuche de los últimos veinticinco años, necesariamente parecen pasar por mis conecciones intelectuales y académicas. Todo ésto hace de nuestra amistad una relación compleja que opera a múltiples niveles; no puedo ni debo presumir una horizontalidad simple y falsa entre nosotras dos. De hecho, todos los debates, todas las críticas hechas al interior de la antropología en los últimos veinte años me advierten que no puedo ni debo pretender una igualdad de condiciones entre nosotras.(13)

Al mismo tiempo, honestamente, no quiero ni malinterpretrar ni exagerar tampoco las diferencias que nos separan. Por un lado, éstas son importantes y están basadas en factores estructurales y sobredeterminados como las clases sociales, el imperialismo, hasta la conquista española y el racismo de 500 años. Pero por otro, hemos construído una amistad entre dos personas específicas que por una serie de razones han logrado comunicarse y apreciarse por encima de las barreras y diferencias. Por tanto, quisiera también refleccionar un poco acerca de cuáles factores, en mis meses de meditación, he llegado a recalcar como importantes en la construcción de nuestra amistad.

Para comenzar, he llegado a creer que Isolde Reuque y yo nos hicimos amigas porque ambas nos sentíamos un poco extrañas o diferentes en nuestros ambientes originales. En una de nuestras conversaciones, cuando me explicaba porqué se ha quedado con su marido a pesar de los muchos problemas que han sufrido, me dijo que era porque los dos eran «ovejas negras». Esta frase, especialmente su significado de marginalidad y la posibilidad de conectarse con otros en la misma situación, es algo que también tiene relevancia para mi. Para Isolde, denota su experiencia como una dirigente mapuche que, a pesar de ser una de las fundadoras de la primera organización étnica mapuche en 1978, tuvo que aprender el mapudungún como adulta porque no se había hablado en su casa. Aunque se pasó años viajando por el sur de Chile ayudando a otras comunidades a revivir la cultura y el ritual mapuches, en su propia comunidad se había dejado de hacer nguillatunes veinte años atrás y, como ella recuerda, a pesar de que lograron celebrar un nuevo ciclo de rogativas comenzando en 1979, fué mucho más difícil «ser profeta en su propia tierra»». Por otra parte, en un movimiento social Mapuche donde muchos compañeros eran de izquierda, Isolde siempre tuvo creencias políticas moderadas y una fe religiosa católica y sincera, algo que le causó más de algunos problemas. Sin embargo ella es profundamente radical en su forma de vivir, porque critica honestamente, sea a amigos o enemigos, y la autocrítica es siempre su primer paso. No tiene pelos en la lengua, aún cuando ésto la hace menos popular entre sus aliados o con las élites políticas de su partido. Su honestidad y valentía, aún cuando teníamos diferentes creencias políticas, hizo posible la confianza y la amistad y además inspiró mi profunda admiración.

De mi parte, aprendí al regresar a Chile en 1996, después de más veinte años, que en realidad yo no pertenecía en ninguna parte. A pesar de mi larga ausencia mi familia chilena, parte de la élite terrateniente tradicional, me aceptó con amor y le dió una cálida bienvenida también a mi esposo e hijos. Sin embargo me sentí fuera de lugar en el Santiago post-pinochetista de los barrios altos y estaba buscando, desesperadamente, otra forma de sentirme conectada en el país donde nací, preferentemente en las márgenes de la sociedad dominante. Al mismo tiempo no rechacé completamente el privilegio de mis conecciones familiares, usándolas en forma puntual para conseguir una entrevista con una familia terrateniente del sur, ganando la confianza de ellos cuando les conté que un tío abuelo mío había sido Presidente de la República. Cuando compartí con Isolde mis ambivalencias al respecto se rió de mi, pero también creo haber detectado detrás de su risa una cierta comprensión de los dolores y contradicciones de vivir en las fronteras sociales y culturales.

A final de cuentas, me he convencido que las dos necesitábamos la colaboración y amistad que dió como

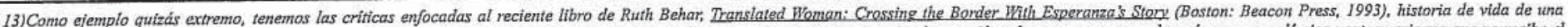

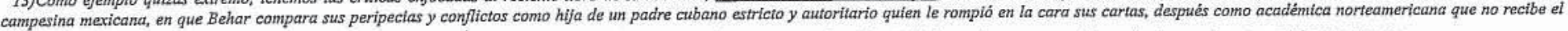
reconocimiento que ella cree merecer, con la vida de Esperanza, una campesina que ha sufrido la pobreza extrema y la violencia fisica, peligrosa y repetidamente, de su padre, su marido y su suegra. 
resultado un testimonio. Isolde se había sentido cada vez más aislada dentro de un movimiento étnico y social al cual había dado un cuarto de siglo de su vida; había visto que este movimiento perdía poco a poco su fuerza y unidad y que no sabía recobrarlas en el momento en que más las necesitaba para la defensa de la cultura y el territorio. Por tanto, ella necesitaba intensamente el tipo de plataforma pública para sus reflecciones y opiniones que le podía brindar un libro sobre su vida. Al mismo tiempo, me dijo varias veces que ella sabía escribir mejor cuando hablaba, e insistió que era una característica fuertemente mapuche, puesto que su cultura habían sido histórica y preferentemente oral; los mapuches, me dijo, siempre sabemos elaborar más bonito en los discursos que con palabras escritas. Ella necesitaba, claro está, que alguien como yocon mi grabadora y las asistentes que contraté en Santiago para desgrabar los cassettes-transformara su narrativa hablada en texto escrito. Yo, de mi parte, necesitaba el reconocimiento y la aceptación que me dieron Isolde, su hija, su hermana y el resto de su familia. Necesitaba un interlocutor desde la sociedad mapuche que me pudiera ayudar a comprender y evaluar las muchas complejidades culturales, políticas y sociales con que me encontré al empezar a estudiar una cultura y un pueblo antes completamente desconocidos para mi. Isolde, su marido Juan y su hermana Elvira supieron ayudarme en este sentido y además reconocer que yo era una investigadora seria a quien le importaba profundizar y respetar. Esto fué especialmente importante para mi, como extranjera no solamente frente al pueblo mapuche sino que también frente a la comunidad de estudiosos mapuchistas, comunidad de expertos de larga duración, mapuches y no mapuches, que por razones muy comprensibles tendía a cerrarse frente a gente de fuera.

El resultado de todo ésto es todavía un libro en proceso de negociación. Desde mayo Isolde tiene en sus manos un borrador completo, aunque sin introducción ni conclusión. Trabajaremos en agosto para completar las revisiones y nuestras propias introducciones y conclusiones, con miras a presentar un manuscrito completo a una editorial hacia finales de 1998. En febrero de este año, cuando le mandé a Isolde los primeros dos capítulos completos, incluí en el paquete una copia de la autobiografía de la activista indígena guatemalteca, Premio Nobel de la Paz, Rigoberta Menchú. Sabía que
Isolde y la Menchú habían sido parte de la misma gira indígena por Europa en 1992, pero también le expliqué por teléfono el otro motivo que tenía para mandársela. «Cuando se traduzca tu libro al inglés»-le dije - 》en Estados Unidos te van a llamar la Rigoberta Menchú chilena. Es importante que empieces a refleccionar sobre lo que va a significar la comparación»».

Una parte de mi agenda para nuestro trabajo en agosto es una conversación sobre las similitudes y diferencias entre el testimonio de Menchú y el trabajo de Isolde, especialmente los contextos comparativos dentro de los cuales se escribieron los dos y las diferentes motivaciones políticas que se tendrían al escribirlos. Menchú dictó su testimonio a una antropóloga venezolana residente en París poco después de haber salido al exilio, todavía con las muertes traumáticas y violentas de sus familiares doliendo frescas, deseando fervientemente dar testimonio sobre la situación guatemalteca a un público internacional. Isolde, por otro lado, dictó su testimonio en su país y región de origen, frente a un movimiento indígena en retirada, capaz y con ganas de refleccionar profundamente acerca de las victorias y las derrotas de los últimos veinte años. Era capaz, en un momento histórico distinto, de ser honesta y crítica frente a las divisiones y los problemas internos, y frente a las dificultades de organizar un movimiento feminista al interior del movimiento y del pueblo mapuche. En este sentido, su testimonio es crítico y reflexivo mientras que el de Menchú era denuncia políticamente urgente. Al mismo tiempo, cuando compartieron una tribuna en la gira indígena por Europa se notó que compartían un mismo deseo y compromiso frente a las culturas originales de las Américas, culturas que han sobrevivido a pesar de las intensas presiones y violentas agresiones de siglos. Hace poco me han informado que la Menchú está por sacar un nuevo libro, secuela del testimonio original; me pregunto cuáles serán las similitudes y diferencias entre este nuevo texto y el testimonio de Isolde.

Cuando una historiadora es aprobada en la asamblea de la comunidad: Reconstruyendo la identidad de Nicolás Ailio

La misma tarde del día que conocí a Isolde Reuque había visitado también al Centro de Estudios Simón Bolívar, ONG establecida durante los años prósperos de la transición por Enrique Pérez, rebelde nato, ex-mirista y 
fumador empedernido que había regresado del exilio en 1989. Un antropólogo temucano me había recomendado a Enrique y al CESB cuando le había comentado que yo tenía interés en localizar a una comunidad mapuche que había colaborado con el MIR, y específicamente con el Movimiento Campesino Revolucionario, durante el gobierno de la Unidad Popular. Como miembro del MIR Enrique había trabajado con varias comunidades mapuches de la región, y por tanto mi colega antropólogo pensó que podría servirme de. buen contacto. Cuando me encontré con él en octubre, durante mi visita anterior, supe inmediatamente que mi amigo había tenido razón. Enrique me dió una lista de varias comunidades que habían trabajado con el MCR y con las cuales él estaba trabajando en ese mismo momento, y yo me ofrecí a investigarlas en el Archivo de Asuntos Indígenas, encontrando sus títulos de merced y otra documentación relevante. Cuando lo llamé en noviembre al regresar a Temuco, ya había logrado encontrar documentación muy interesante para el caso de la comunidad de Nicolás Ailío, y dió la coincidencia de que Enrique se estaría reuniendo con los dirigentes de esa comunidad en esos mismos días. Me invitó a pasar por el CESB durante la visita de ellos para conversar.

Esperé en la antesala del edificio medio destartalado del CESB mientras Enrique y los dirigentes conferenciaban privadamente, $\mathrm{y}$ al rato fuí presentada al presidente y secretario de la comunidad, don Heriberto Ailío y don José Garrido. A pesar de su baja estatura física, especialmente en comparación a don «Chami», el secretario, don Heriberto claramente tenía la autoridad política e intelectual. Después de los saludos, compartí con ellos copias de los documentos que ya había encontrado sobre su comunidad. Don Heriberto los empezó a comentar inmediatamente, caso por caso y hecho por hecho, agregando información que suplementaba lo que se veía sobre la página. Fué especialmente intensa nuestra discusión de los años de la UP. Don Heriberto se refirió a la toma del fundo Rucalán, en la cual participaron familias de la comunidad de Ailío durante la madrugada del 20 de diciembre de 1970, recordando cómo había logrado desalojar al terrateniente y su familia. Al poco rato Rucalán sería transformado en un asentamiento de reforma agraria. También se refirió a una segunda toma, en realidad una corrida de cerco, en 1972 cuando miembros de la misma comunidad habían participado en una restitución parcial, por la vía de los hechos, de 45 hectáreas incluídas en el título de merced de 1906. La usurpación de esta tierra, ampliamente comentada en los documentos que yo había encontrado en el Archivo de Asuntos Indígenas,(14) había ocurrido en 1908, dos escasos años después de recibir el título original. A pesar de que Enrique había trabajado con la comunidad durante los años de la UP y creía conocer bien su historia, expresó su sorpresa al saber de la corrida de cerco de 1972. Se nos hizo claro a todos, por tanto, que mi investigación de archivo podría beneficiar a la gente de la comunidad porque les ayudaría a recobrar partes de su historia que ya casi habían pasado al olvido. Se me invitó a acompañar a Enrique en su próxima visita a Ailío, que casualmente sería el día siguiente. Demás decir que me sentí ilusionada con la idea de profundizar el caso de esta comunidad, especialmente después de haber participado en una conversación tan dinámica que ya me había ayudado a darles carne humana a una serie de huesos archivísticos. "Es una historia increíble de lucha y sobrevivencia», anoté esa misma noche en mi cuaderno de investigación.

Siento el deseo de acompañarlos, de servir un poco de secretaria de la memoria, de hacerles llegar mis apuntes, mis cosas, de presentarles el material que yo recogo para facilitarles un proceso de re-cuento, de dejar constancia de sus luchas. Y ellos, además, pueden ser mis maestros, mis interlocutores. Quiero que nos resulte el proceso de recordar.(15)

Al día siguiente me pasé mucho tiempo esperando, primero porque Enrique llegaba siempre tarde y su llegada a buscarme a mi pensión no fué ninguna excepción; y segundo, porque al llegar a la comunidad la gente de Ailío estaba en asamblea y tardó bastante en invitarme a entrar. Mientras esperaba se me presentó a un residente no-mapuche que trabajaba como mecánico reparando el camión y la trilladora de la comunidad. Resultó que había sido promotor rural durante el gobierno de la UP y que había estado en la cárcel después del golpe. Me invitó a sentarme en su cocina y nuestra conversación se transformó en mi primera entrevista for-

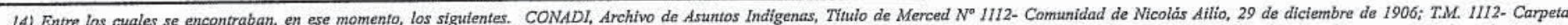

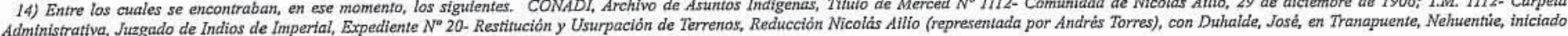
el 25 de abril de 1930.

15) Florencia Mallon, Cuaderno de notas de investigación $N^{\circ} 1,29-11-96$. 
malmente grabada acerca de la movilización popular y la represión en la zona de la costa entre 1970 y 1973. Finalmente, cuando casi había perdido toda esperanza, se me invitó a entrar a la asamblea comunal.

Don Heriberto Ailío me presentó a los.miembros allí presentes, aproximadamente unos veinte entre hombres y mujeres. Explicó que yo era una historiadora que ya había encontrado documentos interesantes sobre la comunidad en los archivos de Temuco y les había dado copias a ellos. Me pidió explicar a los miembros en que consistía mi trabajo y definir para ellos el tipo de ayuda que les estaría pidiendo. Sin estar completamente preparada, tartamudeé un poco al intentar una explicación del proceso de recopilar la historia oral: quería juntar varias versiones y memorias de múltiplies personas sobre la vida y las experiencias de la comunidad, para después tejerlas juntas en una bistoria más grande que sería diferente de todos sus componentes individuales simplemente porque estaríamos combinando distintas perspectivas. Esta idea pareció interesarle a los presentes, aunque también estaban preocupados sobre la cantidad de tiempo que tendrían que dedicarme. A continuación, uno de los presentes expresó una duda. Parece que gente de afuera muchas veces viene a las comunidades mapuches, comentó; y después que hablamos con ellos, dejamos nuestro trabajo para atenderlos, se llevan los resultados de su trabajo a su patria y nunca más sabemos de ellos. Creo que Ud. debe dejarnos un informe sobre lo que ha encontrado antes de irse; así nos queda algo inmediatamente. 'La asamblea entera estuvo de acuerdo, y yo opiné que me parecía una excelente idea. Pusimos fecha para mi próxima visita, a cominezos de enero; don Heriberto nombró a René Ailío, uno de los dirigentes de la nueva generación, anfitrión para mi próxima estadía y yo prometí llegar a la casa de René el 4 de enero.

René Ailío formaba parte del grupo en la comunidad que no iba a mudarse a la nueva tierra que se estaba comprando con un subsidio del Fondo de Tierras de la CONADI, programa especial establecido con la Ley Indígena cuyo propósito era dar restitución limitada en algunos de los casos en que comunidades o familias Mapuches había perdido su tierra en el siglo desde la llamada «Pacificación»). Don Heriberto había dirigido el esfuerzo que llevó a la solicitud exitosa frente a la CONADI y ahora encabezaba el grupo que esperaba mudarse a Gorbea, zona precordillerana ubicada al sur de Pitrufquén. Las 180 hectáreas de tierra habían sido ya compradas y solamente se estaba esperando el fin del papeleo para iniciar la mudanza. Me tomó bastante tiempo empezar a comprender que yo me había tropezado con una situación muy compleja, atreviéndome a entrar a la comunidad en un momento especialmente emocional y doloroso. Los cambios que se estaban dando - una mudanza que dividiría a la comunidad en dos mitades; la realidad de que algunas familias tendría acceso a la nueva tierra y otras no-amenazaban hacer trizas de lo que había sido, durante casi un siglo, la comunidad de Nicolás Ailío. La asamblea a la cual se me invitó el 30 de noviembre de 1996 había tenido la presencia de ambos grupos, los que se iban y los que se quedaban; en ese momento el discurso aceptado y en común era que la comunidad seguiría siendo una, que la gente de ambos lados seguiría trabajando junta y cooperando mutuamente. Un ánimo similar nos acompañó el próximo jueves 5 de diciembre, cuando con don Heriberto, don Chami, Enrique y otros viajamos a Gorbea a ver la tierra que estaban comprando. Pero mediante pasaba el tiempo en los próximos dos meses, las divisiones potencialmente creadas por la compra y la mudanza empezaron a vislumbrarse cada vez con más intensidad.

Pensándolo restrospectivamente, creo que de cierta manera don Heriberto y los otros que se encontraban presentes en la asamblea original vieron en mí una posible forma de sanar diferencias y divisiones. Si yo pudiera facilitarles acceso a una historia en común, una historia de luchas y privaciones colectivas, una historia que los había hecho comunidad y, según el título de merced una familia extendida o linaje, entonces quiza también podría demostrarles porqué tenían que seguir unidos en el presente. Un dirigente político de larga experiencia, don Heriberto quiso que mi investigación reviviera en sus peñis y compañeros una visión más profunda de los motivos de la lucha por la tierra, facilitando así el proceso de mudanza y también la negociación con los que se iban a quedar. Desde mi punto de vista, el hecho de que la comunidad de Ailío estaba por recibir, del gobierno chileno, un subsidio de tierra en reconocimiento de casi un siglo de explotación y dominación, le daba un final particularmente dramático a la historia que yo quería contar. Que una parte de la comunidad había colaborado con el MCR y participado en una 
toma de fundo durante la presidencia de Salvador Allende, y que como resultado varias personas habían sido encarceladas y torturadas por los militares, le agregaba todavía más importancia como caso profundo. Por una serie de razones distintas, entonces, todos participamos en forma entusiasta en el proyecto común de reconstituir la memoria colectiva. Mediante pasaban los meses, sin embargo, y yo me transformaba en interlocutora de ambos grupos-los que se mudaron y los que se quedaron-mi papel parecía cambiar, y en vez de ser una fuerza que promovía la unidad, me transformé en una presencia que podría profundizar las divisiones.

Para explicar este cambio fué necesario hurgar muy adentro en la historia de la comunidad de Ailío, todavía más atrás del desacuerdo que surgió entre facciones de la comunidad al final de los 60, con la Reforma Agraria. En 1938, treinta años después de la usurpación original de 45 hectareas y tratando de evitar una batalla legal sobre problemas de herencia, el hijo del terrateniente que había usurpado la tierra de Ailío acordó vender el fundo Tranapuente-compuesto en parte de las tierras usurpadas-a la Caja de Colonización Agrícola. Usando los atributos legales que le había dado el estado, la Caja le pago la tierra al dueño legal del fundo a precio de mercado y parceló el fundo, ofreciendo retazos individuales a colonos y otros residentes locales. Varios de los colonos que recibieron parcelas se las vendieron posteriormente a otros agricultores locales, dos de los cuales recibieron las viejas tierras de Ailío. Solamente con la declaración de la Reforma Agraria en los años 60 es que se creó nuevamente una apertura hacia los problemas campesinos, y la comunidad se sintió capacitada nuevamente de reabrir el viejo juicio de restitución que se había archivado en los años 30 . Lamentablemente, dada la complejidad del proceso de parcelación y ventas subsiguientes, el caso no fué resuelto facilmente y la gente empezó a perder esperanzas.(16)

Perder esperanzas frente a la extrema pobreza que ya sufría la mayoría de las familias de Ailío, era una opción verdaderamente devastadora. Con la maduración de una nueva generación en la comunidad la cantidad de tierra por familia había disminuído todavía más, y para el comienzo de los años 60 muchas familias tenían un promedio de media hectárea por persona. Según un censo local a mediados de esa misma década, en el mejor de los casos la gente lograba cultivar la mitad de lo que tenían porque la tierra ya estaba agotada o erosionada y había escasez de herramientas y capital.(17) ¿Qué hacer? En 1969 se organizó un comité local, compuesto de gente de las comunidades de Ailío y Pichingual, para discutir el asunto. Entre las alternativas que discutieron fué la posibilidad de tomar uno de los fundos cercanos y con el tiempo, la discusión empezó a enfocarse en el caso del fundo Rucalán. Alguna gente de Ailío estuvo en desacuerdo. Querían recobrar sus tierras originales y lo querían hacer legalmente, «por las buenas». En 1969 y 1970 la gente más activa en el comité local, que cada vez tenía más conecciones con el MIR a través del MCR, lo veía en forma distinta. Pensaban que la justicia para el campesino no se podía conseguir solamente por la vía legal; la acción directa, técnicamente ilegal, sería necesaria. Este fué el razonamiento que llevó a la toma de Rucalán, y creó también una ruptura dentro de la comunidad de Ailío que se abriría todavía más a los tres años con el golpe militar.(18)

Obviamente, si yo logré acceso a esta información a través de las entrevistas, la gente de la comunidad no se había olvidado de estos hechos y desacuerdos; pero estoy convencida que el mismo proceso de recordarlos y discutirlos nuevamente, especialmente en el contexto de las tensiones ya creadas por la mudanza, sirvió para profundizar y justificar las divisiones ya existentes. Todo ésto se intensificó más con mi uso de métodos participativos y de diálogo entre entrevistados, y también porque tomé muy en serio la condición puesta en la asamblea de noviembre, sobre compartir los resultados de mi investigación antes de partir. Durante los próximos seis meses usé las desgrabaciones de las entrevistas previas, los resultados de mis conversaciones con otros miembros de la comunidad, y las fotocopias de artículos de la prensa y otros documentos para suscitar interpretaciones y reacciones de mis entrevistados. También presente dos informes de investigación en Gorbea y Tranapuente. Especialmente en Gorbea, don Heriberto Ailío y su hermana doña Eduardina entabla-

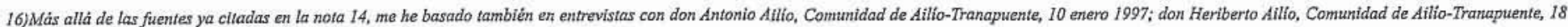
enero 1997 y Temuco, 18 abril 1997. Para una discusión más completa de la venta y parcelación del findo Tranapuente, consultar la siguiente sección de este ensayo.

17) CONADI, Archivo de Asuntos Indigenas, T.M. 1112-Carpeta Administrativa, Censo de la Comunidad de Nicolás Aillo, 1963.

18) Entrevistas con don Antonio Ailio, 10-1-97, quien usó la frase "por las buenas"; y don Heriberto Allio, 18-1-97, 18-4-97.
} 
ron conversaciones dinámicas conmigo, corrigiendo elementos de mi análisis y disputando las interpretaciones de las personas con quienes estaban en desacuerdo. El 20 de marzo de 1997 en Gorbea, una asamblea de recién mudados, algunos todavía sin casa, interrumpió su discusión de estrategias de sobrevivencia, a pesar de lo apremiante de su situación, para discutir conmigo mi primer informe sobre la historia de la comunidad.

A la larga, creo que mi trabajo de tejer los hilos dispersos de la memoria comunal ayudó a dramatizarles a los miembros de la comunidad las razones que apoyaban la división, no la unidad. Ahora bien, no puedo ni debo tomar excesiva responsabilidad en esta situación, puesto que el mismo proceso de implementación de la Ley Indígena-la que había creado la CONADI y el Fondo de Tierras-sirvió para dividir al movimiento mapuche y a muchas comunidades. La falta de fondos para facilitar la adaptación una vez que ya estaban en Gorbea también incrementó la desesperación de las familias que se habían mudado, y por tanto facilitó la división y la falta de solidaridad. Yo no fuí, por tanto, el factór causante del conflicto entre las mitades de la comunidad, pero sí me transformé en su narradora y testigo, compartiendo los resultados de mis observaciones con los dirigentes de la comunidad. Terminé acompañándolos en su viaje difícil y doloroso, a veces iluminándoles el camino pero nunca trazando uno nuevo. Sigo trabajando con la gente de Ailío, después de mi vuelta a Estados Unidos necesariamente a la distancia;, hablando con los nuevos técnicos agrícolas que intentan ayudarles, de vez en cuando sugiriendo una fuente de financiamiento. Seguiré como testigo y narradora de este presente y futuro que sigue desenvolviéndose.

El encuentro de la historia oral con el archivo: La muerte de... ¿cuál Duhalde?

El 11 de enero de 1997, de visita con René Ailío y su familia en Tranapuente, me entrevisté con su padre don Antonio. Como hacía siempre en mis entrevistas, compartí con don Antonio algunos de los documentos sobre la comunidad que había encontrado en los archivos de Temuco. Resultó que el padre de don Antonio había sido uno de los dirigentes que resistieron la usurpación original que sufrió la comunidad en manos del comerciante y poderoso terrateniente local José Duhalde. Don Antonio recordaba claramente la frustración de su padre en esa lucha fallada. También fué don Antonio que me mencionó, por primera vez, la parcelación del fundo Tranapuente-que incluáa, por supuesto, las tierras originales de Ailío- por la Caja de Colonización Agrícola. Cuando le pregunté cuál habría sido la fecha de esta nueva expropiación, se puso un poco vago: quizá como en 1920, me dijo. Cuando le pregunté quién había sido presidente en ese momento, sin embargo, su respuesta fué enteramente confiada: don Carlos Ibáñez del Campo. Y refiriéndose todavía a Duhalde, me ofreció un último comentario: lo mataron también, quiso enrollar Duhalde en Puerto Saavedra a un caballero que tenía molino, le consiguió plata y después el caballero quiso que le devolvieran y él decía que no tenía, que firmara un cheque, no tengo plata le decía. Así que el caballero se aburrió al último; no le quiso cobrar más y un día vino temprano y lo vió que estaba ahí en su oficina Duhalde, y vino y le corrió bala el caballero y lo mataron, entonces terminó Duhalde.(19)

Con esta entrevista comenzó mi intento de confirmar estos hechos en la documentación archivística. Tenía pocas pistas: que la Caja de Colonización Agrícola había comprado el fundo y que posiblemente había sido durante la presidencia de Carlos Ibáñez del Campo. Se complicaba aún más la situación, puesto que Ibáñez había ocupado la presidencia dos veces: la primera a final de los años 20 y la segunda en los años 50 . ¿En cuál período debería enfocar mis pesquisas? ¿En cuál ministerio iba a encontrar la Caja de Colonización? Durante los meses siguientes busqué en vano por los fondos ministeriales de Agricultura y Tierras y Colonización. Solamente cuando presenté mi primer informe de investigación en Gorbea en marzo es que recibí mi segunda pista. Había incorporado al informe la versión de los hechos presentada por don Antonio Ailío y recibí respuestas sobre el asesinato de Duhalde de varias personas ahí presentes. Se recordó que el asesino habría sido Juan Bello, cuñado de Duhalde, quien trabajaba para él. Cada vez que Bello trataba de conseguir que le cancelara una deuda, Duhalde lo amenazaba de muerte. Finalmente, me contaron, Bello no tuvo más alternativa 
que presentarse muy temprano en la oficina de su cuñado, con su pistola ya apuntada, y matarlo. Adicionalmente estaba presente en esta reunión un joven mapuche de una de las comunidades de la Isla Huapi, cerca a Puerto Saavedra. También participó en la discusión porque su abuela había servido de nana a los hijos de Duhalde. La gente hacía cola en la puerta de la oficina de Duhalde, comentó, a veces quedándose parados el día entero, solamente para poder hablarle. También tenía una fábrica en Puerto Saavedra y le pagaba poco o nada a sus trabajadores. Si alguien se quejaba, Duhalde lo citaba a la fábrica y simplemente lo tiraba a la caldera.(20)

Cuando presenté mi último informe a la comunidad en junio de 1997, no había encontrado más información. Mientras buscaba corroborar el caso de Duhalde había descubierto una serie de datos importantes sobre otros temas, pero nada acerca del caso que más me interesaba. En mi último informe a Ailío sugerí que quizá la parcelación del fundo había sido originada por la muerte de Duhalde.(21) Aunque todavía me quedaban algunas semanas de investigación en Santiago después de mi regreso de mi último viaje a Temuco, ya me había convencido de la inutilidad de la búsqueda. Había logrado confirmar lo más importante, pensé: Duhalde había muerto como resultado de su larga trayectoria de abusos a nivel local. Más que cualquier detalle que supuestamente se habría preservado en el acervo archivístico después de haber desaparecido de la memoria humana, era esta trayectoria general de abuso lo que tenía que enfatizar. Al poco rato de haberme resignado a lo inevitable, durante una búsqueda rutinaria por un tomo de correspondencia de la Intendencia de Cautín para el año de 1939, me tropecé con una veta de oro.

«E1 día 26 de Febrero próximo ppdo, a las 14 horas, estalló un incendio en el fundo Tranapuente, ubicado en el Distrito de Nehuentúe», escribió Emeterio Gómez Gutiérrez, Mayor de Carabineros al Intendente de Cautín. Pero fué un comentario posterior, casi mar- ginal, que más me llamó la atención. «Dicha propiedad había sido adquirida últimamente por la Caja de Colonización Agrícola a los Sres. Duhalde y Cía», escribió Gómez, agregando que don José Duhalde y su hijo Graciano habían presenciado el siniestro. Como recién había encontrado otro documento de octubre de 1936 sobre el fundo Tranapuente, en donde no se mencionaba ninguna venta, y ahora tenía un documento de febrero de 1939 en que ya la compra se había llevado a cabo, podía definir un período relativamente corto dentro del cual comenzar una búsqueda intensiva en los documentos de la Caja.(22) De todas maneras significaba pasarme, por año, unos ochenta tomos de expedientes y un número parecido de decretos para el Ministerio de Tierras y Colonización; pero al menos tenía ya una meta clara. Mientrás tanto, también seguí consultando el Fondo Intendencia de Cautín, puesto que estaba bien organizado y no tan abundantes por año; y además todavía estaba buscando material sobre otros temas.

Fué literalmente en mis últimos días de investigación, ya con un pie en el estribo, que encontré los dos documentos que buscaba. El primero fue el decreto sobre la compra del fundo Tranapuente. Resultó ser Graciano Duhalde, no su padre José, quien ofreció el fundo a la Caja de Colonización Agrícola. Las evidencias sugieren que lo hizo para frustrar una posible demanda legal de su hermana por el lado de su padre, quien a la muerte de la madre de ella no había recibido lo que consideraba su justa porción de la propiedad del padre común-propiedad que incluía, por supuesto, el fundo Tranapuente. Según el decreto de Tierras y Colonización, la fecha de entrega a la Caja habría sido el 30 de septiembre de 1938, no durante una de las presidencias de Ibáñez, pero sí durante la presidencia de Pedro Aguirre Cerda, el único otro de esa época que había intentado reformas importantes.(23) $\mathrm{Y}$ aunque no tengo todavía evidencias directas, es posible que el papel medio oscuro de Graciano en las manipulaciones de las herencias y propiedades familiares podría haber tenido ingerencia en el otro evento sobre el cual encontré evidencias la misma semana.

20)Reuniön en Aillo-Gorbea, Notas de investigación, 20 marzo 1997.

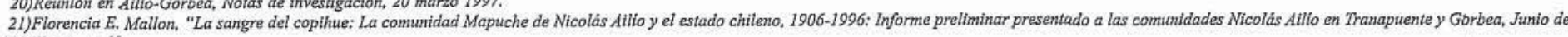

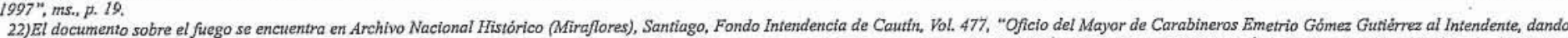

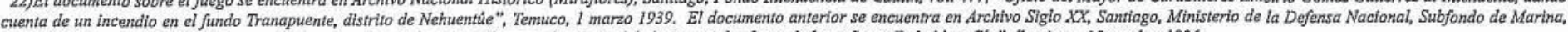
Vol. 2959, Decreto $N^{9} 1482$ : "Renovando la concesión de dos atracaderas en la ribera del rio Imperial a favor de los señores Duhalde y Cia", Santiago, 15 octubre 1936.

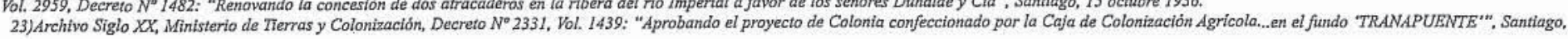
30 sept. 1938, y documentos adjuntos. 
No fué José, sino que Graciano Duhalde, quien fué asesinado el 25 de diciembre de 1940. El informe presentado al Intendente por el Prefecto de Carabineros en 28 de diciembre confirmó muchos de los detalles recordados por don Antonio: un conocido lo mató a balazos, en su oficina, temprano en la mañana. El asesino se anotó como Lorenzo Henríquez Escar, dueño de un molino en Puerto Saavedra; después del crimen regresó a su oficina en dicho molino y se suicidó. Los carabineros lo encontraron todavía vivo pero ya «en estado agónico», una herida de bala en la sien, su pistola a su lado. «En el escritorio de dicha oficina», escribió el Prefecto, «se encontró una carta sin terminar, en la que se refiere que dió muerte al Sr. Duhalde; tratándolo de bandido, usurpador de tierras».(24)

¿Tenía Hernández una relación con la hermana por padre de Graciano Duhalde, y sería ésta la razón por la cual lo llamó un usurpador de tierras? Es posible, y así lo habrían sugerido en Ailío-Gorbea al recordar que Duhalde fué muerto por un cuñado. Por el momento no tenemos evidencias directas, y además es importante recordar que la familia Duhalde tenía ya medio siglo de trayectoria como usurpadores de tierras en toda la región. Pero lo que sí podemos establecer, y con texturas y significados muchísimo más ricos y complejos que antes de haber decubierto estos documentos, es que José y Graciano Dubalde se habían mezclado, en la memoria de la gente de Ailío, hasta formar una sola figura de terrateniente abusivo y usurpador que finalmente había recibido lo merecido. Esto es, a final de cuentas, el significado más interesante y profundo que podemos rescatar de este diálogo entre la historia oral y el acervo documental.

Hasta cierto punto, la pregunta con la cual comencé esta reflección se vuelve irrelevante para la historia oral a nivel local. No importa cuál Duhalde fué asesinado, porque para los efectos de la moraleja del terrateniente abusivo a quien matan por los abusos que ha cometido, los dos Duhaldes se vuelven uno. Aunque para la historia escrita y más académica vale la pena establecer la versión «correcta» o «verdadera» de los hechos, resulta ser solamente una parte de la historia más general. Tiene igual importancia la «mentira»: que solamente un Duhalde usurpó las 45 hectáreas de Ailío, las transformó en fundo y se las vendió a la Caja de Colonización Agrícola; que este mismo y unitario Duhalde era conocido como abusador por toda la región, rehusando pagar sus deudas y explotando a los trabajadores y campesinos (recordemos que en la versión de la Isla Huapi, Duhalde literalmente consumía los cuerpos de sus trabajadores rebeldes, arrojándolos a la caldera que producía energía para su fábrica); y que este mismo, único Duhalde finalmente recibió lo merecido al ser asesinado en su oficina por un socio comercial ofendido. Este cuento, esta leyenda o moraleja 1ocal, penetra hasta el mismo corazón de las relaciones de poder locales, con un corte limpio, fácil y eminentemente satisfactorio: al terrateniente explotador, corrompido y corroído hasta sus mismas entrañas, tarde o temprano le saldrá el tiro por la culata.

Y bueno, en realidad, ¿a quién le pertenecían esas armas?. La operación militar de Nehuentúe

Uno de los aspectos más fascinantes del caso de Ailío fué su papel como blanco de la operación militar de Nehuentúe. El 29 de agosto de 1973, efectivos del Tercer Grupo de Helicópteros de la FACH se unieron al regimiento Tucapel de Temuco en una acción que tenía como propósito barrer con todos los focos izquierdistas identificados en la región de la costa, entre Carahue y Nehuentúe. Esta zona incluía a la comunidad de Ailío y además al asentamiento de reforma agraria que se había establecido en el ex-fundo Rucalán. Esta operación militar se llevó a cabo sin conocimiento ni autorización del gobierno civil y se justificó como parte de una campaña general de control de armas entre la población. Según el coronel Pablo Iturriaga, comandante del regimiento Tucapel, era necesario efectuar una operación en la zona de Nehuentúe-nombre del fundo y del pueblo que fueron los blancos principales-porque el MIR habría establecido allí una fábrica de armas y escuela de guerrillas.(25)

Cuando discutí la operación de Nehuentúe por primera vez con don Heriberto Ailío, me dió la misma versión de los hechos que seguramente les había dado a sus torturadores después de que fué encarcelado en sep-

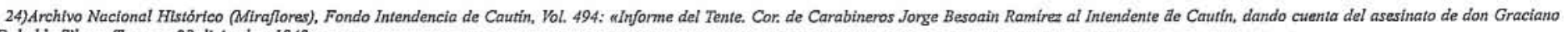
Duhalde Sllvan, Temuco, 28 diciembre 1940.

25)El Diario Austral lunes 3 de septiembre de 1973, pag. 1; y la conferencia de prensa que dió Iturriaga el 5 de septiembre, reproducida en El Diario Austral miércoles 5 sept. 1973, pags. 1, 2. 
tiembre de 1973. No habían armas, me dijo. Ellos no habían hecho nada. Los militares habían fabricado el cuento entero, y habían exhibido sus propias armas en el regimiento para inculpar a los campesinos. A todos los que fueron arrestados en el caso Nehuentúe nunca se les probó nada, explicó, aunque estuvieron en la cárcel un mínimo de dos años. Obviamente no se necesitaban más pruebas de su inocencia, cuando a mediados de los 70 los criterios de evidencia manejados por los militares eran flojos en el mejor de los casos. No podía estar más claro, en la memoria y estimación de don Heriberto, que los presos de Nehuentúe eran víctimas inocentes, chivos expiatorios en una lucha general por el poder.(26)

Una imagen muy similar se reprodujo, el mismo día del golpe, en un reportaje publicado en el último número de Punto Final sobre los abusos a los derechos humanos cometidos en Nehuentúe. Basado en el testimonio de una mujer mapuche de la región que el artículo identificó como Margarita Paillao, campesina que vivía en el ex-fundo Nehuentúe, el reportaje detalló los múltiples sufrimientos que durante la operación habían vivido los habitantes del lugar. «Parecía que era el último día final de la vida y que no iba a existir nadie ya», dice Paillao al abrir el artículo. «Las compañeras se volvieron puro llanto de sentir los gritos y los lamentos de sus maridos». Llegaron tres helicópteros, según la Paillao, como a las nueve de la mañana al CERA Jorge Fernández, ex-fundo Nehuentúe, y los soldados procedieron a allanar las casas, incluyendo la suya, donde le robaron plata. Después el que estaba a cargo empezó a leer una lista de las personas a quienes buscaban y fueron deteniendo a los que encontraron. «A los detenidos se les subió al segundo piso de la casa patronal», prosigue el artículo basado en el testimonio de la Paillao. «Las ventanas de la habitación donde se les llevó estaban abiertas, y desde abajo los campesinos podían ver perfectamente lo que ocurría en el interior». Paillao pudo ver que desnudaban a los prisioneros y después escuchó unos tremendos golpes, seguidos de gritos, llantos y lamentos. Después de presenciar una serie de torturas, las cuales detalla en el artículo, Paillao tuvo un ataque de nervios y fué llevada a Puerto Saavedrá.
Cuando regresó más tarde con el médico no le dejaron entrar. Entre los individuos a quienes ataron a helicópteros, llevándolos en vuelo, suspendidos de sus cinturas, para que confesaran dónde estaban las armas, estuvo Orlando Beltrán, compañero de la Paillao y presidente del Centro de Producción (CEPRO) que formaba parte del CERA Jorge Fernández. Beltrán pasaría cinco años en la cárcel, con enfermedades endémicas causadas por la tortura.(27)

Entre las versiones de estos eventos que aparecen en la prensa local y nacional, dos versiones antagónicas de los hechos de Nehuentúe reclaman ser la verdad. La versión de la oposición al gobierno popular, reproducida en el periódico temucano El Diario Austrial y en los diarios nacionales El Mercurio y Las Ultimas Noticias, pinta a los campesinos del sector reformado como revolucionarios empedernidos y predispuestos a atacar en sus propios hogares a los pacíficos ciudadanos de la región, o alternativamente como víctimas inocentes de una violenta estafa de extrema izquierda que habría transformado a la zona de Nehuentúe en fortaleza o bunker mirista. En tal contexto, se ve a la operación de Nehuentúe como una liberación de la dominación del MIR, y cualquier protesta acerca de los abusos a los derechos humanos serían calumnias injuriosas.(28) La otra versión aparece en las publicaciones que apoyan, o que se ubican a la izquierda de, el gobierno de la UP. No solamente en el artículo de Punto Final ya citado, sino que también en Puro Chile, Clarín y La Nación se publicaron una serie de artículos acusando a la derecha de confabulación y caracterizando como ridículo cualquier cargo de que los campesinos mapuches, tan pobres que casi no tenían plata para pagar sus necesidades diarias, pudieran estar acumulando armas o entrenándose militarmente. En esta segunda versión, los cargos de tortura que los habitantes del lugar presentaron en contra de los militares son vistos como violaciones de los derechos y los cuerpos de ciudadanos de integridad, gente trabajadora e inocente.(29)

Estas dos versiones antagónicas de los eventos de Nehuentúe definieron, no solamente para los militares sino que también para los prisioneros, los parámetros

\footnotetext{
26) Entrevista con don Heriberto Aillio, 18-1-97,

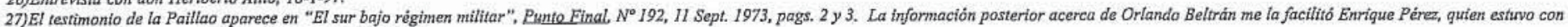
27) El testimonio de la Paillao aparece en "El sur bajo régin.

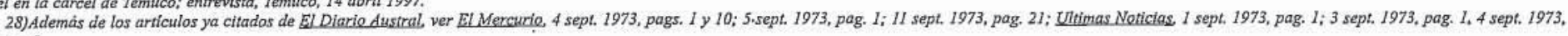
pag. 2.

29) Clarin 5 sept. 1973, pag. 4; 6 sept. 1973, pag. 10; La Nación 6 sept. 1973, pag. 32; Pure Chile 5 sept. 1973, pag. 2; 5 sept. 1973, pag. 4; 6 sept. 1973, pag. 9.
} 
discursivos dentro de los cuáles se ha seguido pensando y discutiendo el caso hasta nuestros días. Cuanto más profundamente lo investigaba, más me convencía que las dos versiones opositoras se habían articulado en un solo baile conceptual cuya coreografía hacía más difícil comprender lo que había pasado en realidad. No sorprende que fué más fácil para mí demostrar la falsedad de la versión militar. Para comenzar, los cargos publicados en El Mercurio y Las Ultimas Noticiasque se habían arrestado cincuenta guerrilleros, que en el ex-fundo Nehuentúe se descubrió un bunker de cemento lleno de ametralladoras, bombas y otras armas extremadamente peligrosas, o que Puerto Saavedra había sufrido un reino de terror bajo la dominación de comandos de pelo largo y bigotes al estilo mandarínresultan risibles hoy en día.(30) Pero aún las versiones más sobrias y consideradas de la posición militar enfatizando las acumulaciones de armas y la escuela de guerrillas, no reciben apoyo sustancial de las evidencias, aún de las que presentó el mismo coronel Iturriaga en su conferencia de prensa del 5 de septiembre. Allí exhibió el armamento decomisado, fotos del cual aparecieron en la prensa local. Estas fotos múestran poco más que algunos rifles, palos, pistolas y bombas molotov. Hasta los armamentos más famosos, las supuestas bombas anti-tanque también conocidas como «vietnamitas» que, según Iturriaga, podrían decimar a una cuadra entera, resultan ser de fabricación casera, hechas en ollas y caserolas comunes y corrientes. En la foto se pueden contar unas veinte en total. ¡Esto no me parece una fábrica de armamentos! Adicionalmente no he encontrado ninguna evidencia, directa o indirecta, de que había en el lugar una escuela de guerrillas. De hecho, uno de los organizadores del MIR que trabajó en la zona señaló que hubiera sido demasiado osado entrenarse allí, ipuesto que el ex-fundo Nehuentúe estaba a plena vista del puesto local de carabineros!(31)

Pero la relativa facilidad con que hoy podemos desprobar la versión militar no cambia el hecho de que en el momento del golpe y en los años subsiguientes de dictadura militar fué esta versión la dominante en el país. Su dominación fué asegurada, claro está, por la censura y la colocación de historias falsas en los diarios que so- brevivieron. Pero también fué asegurada a través de la represión y la violencia. Mediante arrestos, torturas y desinformación los militares lograron esconder las verdaderas dimensiones de los abusos a los derechos humanos que se cometieron en la operación de Nehuentúe y sepultar el hecho de que era un ensayo para el golpe, uno de varios que se llevaron a cabo en lugares estratégicos durante el mes de agosto de 1973. A finales de septiembre de ese mismo año ya no existía conciencia pública de que en Nehuentúe los militares habían probado ya la mayoría de las tácticas que se utilizarían masivamente despues del golpe del 11 de septiembre: allanamiento y destrucción de residencias privadas; intimidación de la población en general; golpes y tortura, incluyendo métodos ya harto conocidos como colgar a la gente de sus pies, aplicarles electricidad en sus testículos, sumergir sus cabezas en pozos de aguas servidas, forzarlos a tomar agua hasta estar «empipados» y después saltar sobre sus estómagos, colgarlos de helicópteros y sumergirlos en el río. La conciencia de estos hechos, por un momento presente en la prensa de izquierda antes del 11 de septiembre, sería rápidamente borrada por una campaña de desinformación sobre los motivos y métodos de la operación.(32)

«Mentí porque me pagaron», pronuncia en grandes letras uno de los titulares en primera plana de E1 Diario Austral del 28 de septiembre de 1973. Se trata de una entrevista hecha a una tal Gertrudis Quidel Quidel, identificada en el artículo como «el verdadero nombre de la mujer presentada en Canal 7 de TV con el nombre de Margarita, y que en un programa difundido al país denunció torturas y flagelaciones supuestamente hechas por las FF. AA.» en Nehuentúe. Según se nos informa, Gertrudis Quidel no presenció nada en Nehuentúe cuando llegaron los «aviones», porque le dió un ataque y tuvo que ir al hospital en Puerto Saavedra. Al regresar, se encontró con una periodista que supuestamente le «escribió a máquina» lo que tenía que decir. Despues, continúa la Quidel, el Intendente de Cautín le dió plata para ir a Santiago a contar la historia, y una vez en la capital el presidente Allende también le dió dinero. Finalmente, asevera, la misma periodista le dijo, al regresar de Santiago, que los militares la iban a matar

30) Las Ultimas Noticias, 3-9-73, pag. 1, 4-9-73, pag. 2; El Mercurie 4-9-73, pags. 1, 10, 5-9-73, pag. 1, 11-9-73, pag. 21.

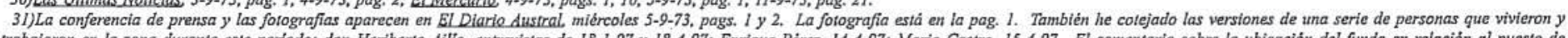

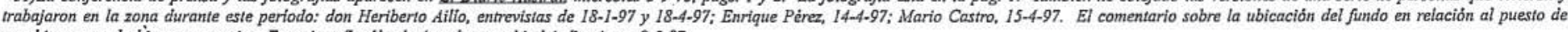
carabineros me lo hizo en entrevista Francisco Sepuilveda (nombre cambiado), Santiago, 9-5-97.

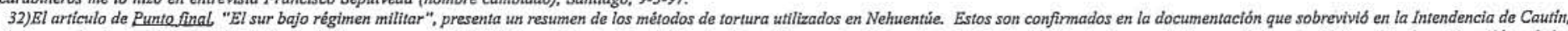

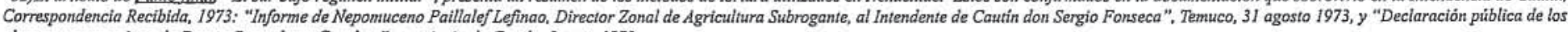
obreros y campesinos de Puerto Saavedra y Carahue", provincia de Cautin, 2 sept. 1973. 
por lo que había dicho y, si cambiaba su historia, los miristas la iban a matar. «"Ellos (se refiere a los miristas del CERA Jorge Fernández) eran los amos y señores, y ¿a quién iba a recurrir, si ellos mandaban?'. A veces gastaba hasta 3 quintales de harina atendiéndolos».(33)

Esta historia apareció el día después de que el exintendente de Cautín y la periodista nombrada por la Quidel fueran arrestados en conección con el caso. Sergio Fonseca, el ex-intendente, se mantuvo bajo arresto domiciliario, mientras que la periodista fue arrestada en Santiago, torturada, y mandada a Temuco para ser procesada por tribunal militar. Bajo la ley marcial en efecto en ese momento, el cargo era sumamente serio: injuria a las fuerzas armadas.(34)

Gertrudis Quidel se llamaba en realidad Margarita Raío y era la misma Margarita Paillao que en Santiago, en los días inmediatamente anteriores al golpe, había presentado testimonio sobre los abusos a los derechos humanos en Nehuentúe. A la periodista Fireley Elgueta se le nombró para acompañarla en Temuco, en una reunión de funcionarios del Ministerio de Agricultura donde tamibén se decidió unánimemente que la información de Nehuentúe era suficientemente grave para llevarla personalmente a la capital. La delegación que viajó a Santiago había incluído a Elgueta y Raío y había ido primero a conversar con el Ministro de Agricultura; dada la gravedad del caso, fueron invitados posteriormente a la Moneda a conversar directamente con el presidente Allende. En la reunión con Allende escuchó también el testimonio de la delegación el comandante de la FACH general Gustavo Leigh, poco después miembro de la junta militar. Cuando Leigh escuchó hablar de la participación de la FACH de Temuco, palideció y empezó a tomar rápidas notas. En la segunda mitad de septiembre, solo veinticuatro horas después de la llegada de Leigh a Temuco, se dieron las órdenes de arresto para Fonseca y Elgueta.

A Margarita Raío la torturaron en Temuco en el Regimiento, amenazando las vidas de sus hijos para forzarla a cambiar su historia. Cuando Fireley Elgueta fué traída a la cárcel de Temuco, carearon a las dos muje- res. En ese mismo momento Raío volvía a la cárcel del regimiento, clara señal de que había sido interrogada. Los soldados la hicieron caminar frente a una fila de prisioneras, entre las cuales se encontraba Elgueta. Al comienzo la Raío intentó no reconocerla, seguramente intentando protegerla. Pero las inconsistencias entre las versiones de las dos mujeres hiceron claro que Raío estaba mintiendo. Una vez que reconoció la mentira la soltaron, ya una mujer destrozada.(35)

Más tarde se supo que Margarita Raío estaba pololeando con un carabinero. Un día, cuando llegaron visitas a la cárcel de Temuco a ver a los prisioneros de Nehuentúe, trajeron la noticia de que Raío había salido una noche con su pololo, dejando solo a Luciano Ernesto, el hijo suyo y de Beltrán. La casa se incendió y el niño murió. Cuando Beltran recibió esta noticia se enfermó gravemente. Después que lo soltaron de la cárcel en 1978 simplemente desapareció; ni sus viejos amigos y sus compañeros supieron más de él. Tampoco se sabe sobre Margarita Raío; estará en la Argentina, dicen, explicación común entre la gente del sur cuando a alguien se le pierde el rastro.(36)

Bajo tales condiciones, cuando se destruyeron, en forma rutinaria, vidas y cuerpos para asegurar la dominación de la versión militar de los hechos, no sorprende que los sobrevivientes como don Heriberto Ailío se agarraran tenazmente a la contra-versión, a la versión de su propia inocencia que a final de cuentas contenía muchísima más verdad que su contraparte. La visión de los arrestados como simples víctimas inocentes recibió apoyo también del movimiento de derechos humanos que surgió durante la dictadura y de las versiones más difundidas y conocidas del discurso post-autoritario de la Comisión de Verdad y Reconciliación, que tendían a enfatizar el recuento de las «víctimas» de la represión.(37) Pero a la larga, una de las dimensiones en común de todas las historias de inocencia y abuso me resultó cada vez más preocupante: al pintar a los campesinos de la región como simples «víctimas» de la represión militar, estas historias les quitaban su capacidad de acción, legitimidad política y complejidad humana.

\footnotetext{
33) «La mapuche de 'Vamos Mujer' en TV-7: 'Menti porque me pagaron'», ElDiario Austral Viernes 28 de Septiembre de 1973, pp. I y 8. Cita en la p. 1 .

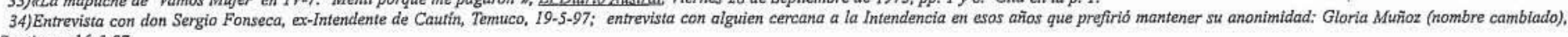
Santiago, 16-5-97.

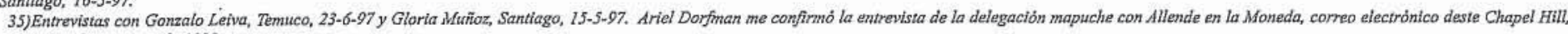
North Carolina, de 1998.

36)Entrevistas con Enrique Pérez, Tenuco, 14-4-97; Gloria Muñoz, Santiago, 15-5-97; Heriberto Ailio, Temuco, 18-4-97.

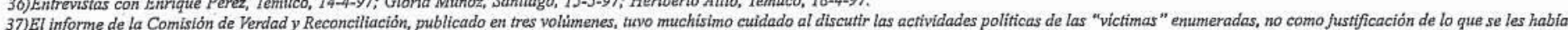

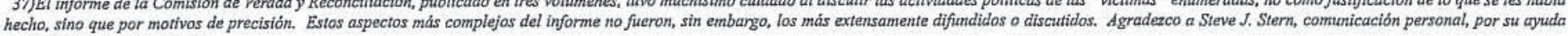
en establecer esta distinción.
} 
Llegué a convencerme de que esta imagen de la gente de Nehuentúe como corderos llevados al sacrificio, aunque comprensible y quizás inevitable dadas las condiciones existentes en Chile después de septiembre de 1973, hacía muy difícil recordar que muchos de ellos habían estado involucrados en un esfuerzo moralmente legítimo, aunque quizá miope, de construir la justicia social. ¿Había alguna forma de enfatizar y preservar su inocencia, mientras que también se respetaba su visión y su activismo políticos?

Esta fué mi motivación principal durante mi última entrevista con don Heriberto Ailío en Temuco en abril de 1997. Para entonces ya tenía suficiente evidencia de otras fuentes para confirmar la existencia de algunas armas, y por lo menos la manufactura informal de vietnamitas, en Nehuentúe.(38) Cuando le mostré las fotografías de El Diario Austral y le pregunté qué pensaba al respecto, don Heriberto me respondió:

Bueno, la verdad es que es eso. Pero no eran muchos, porque eso dependía también de plata y dicen que era gente pobre nosotros, no teníamos. Y los otros armamentos que pusieron ellos después al final, parą declarar que era una escuela guerrillera, una escuela de todos los armamentos que se estaban haciendo, y no era así. No era tanto como lo pusieron ahí en el diario... Porque resulta que son puras mentiras, puras cosas mentiras. Sí que se estaba preparando, sí, se preparaba, preparando como ellos se preparaban. ¡Cómo nosotros nos íbamos a quedar a manos cruzadas! Entonces nosotros sabíamos que ellos estaban preparándose para dar un golpe de Estado y para reprimir a los pobres, a toda la gente...Y así fué.(39)

Mediante avanzábamos con la entrevista, don Heriberto consiguió liberarse cada vez más de las trabas discursivas de una excesiva inocencia, refleccionando más abiertamente sobre la naturaleza y las consecuencias del activismo político en su región. Liberado de la necesidad de presentarse a si mismo y a sus compañeros como neófitos, respondiendo también a otros documentos que yo había encontrado sobre el CERA Arnoldo Ríos, ex-fundo Rucalán, don Heriberto me tejió una narrativa compleja y coherente sobre sus motivos en apoyar la acción directa durante los años de la Unidad Popular. Ya en 1970, confirmó, era miembro del MCR y había ayudado a formar un comité local de recuperación de tierras. Aunque la gente de Ailío había luchado por muchos años tratando de conseguir la restitución de las 45 hectáreas expropiadas por Duhalde en 1908, esa tierra ya se encontraba en manos de pequeños propietarios y los miembros del comité se preguntaron si realmente deberían seguirles juicio a gente local no tan diferente a ellos, potencialmente sus aliandos en la lucha social. «Necesitábamos esas tierras», señaló, y pensábamos que teníamos que luchar de esa forma y el gobierno de Allende estaba amenazando, Allende decía que había que ir a la expropiación, expropiación legales...Y nosotros dijimos...si vamos a apoyar nosotros el gobierno, pero el gobierno no lo va a saber y lo vamos a hacer nosotros...Y eso fué lo que nos llevó a hacer la toma del fundo, e incluso nosotros después de eso, cuando ya se empezó la toma del fundo, tiene que respaldarnos este gobierno, que era el gobierno de nosotros, que es de nuestros campesinos y los pobres, así que fuimos.(40)

A los pocos días de tomar Rucalán los campesinos fueron víctimas de una retoma a mano armada de parte del terrateniente y sus amigos en que hubo varios heridos, pero el gobierno nombró un interventor para administrar el fundo en conflicto y al poco tiempo éste contrató a los mismos campesinos para que trabajaran la tierra. En ese momento, recordó don Heriberto, nosotros ahí llegamos a trabajar, a limpiar. El gobierno lanzó un plan de trabajo para nosotros, un plan de trabajo favorable a nosotros, entonces nosotros limpiamos y en eso el gobierno aportó en plata mensualmente para que nosotros pudiéramos trabajar. Entonces eso hizo el interventor, el interventor dió todo el fundo y todo el fundo estaba en malas condiciones...y por eso fué expropiado ese fundo a la fuerza del interventor, el interventor pasó todas esas cosas, hizo un desplazamiento de todo lo que había, lo que pasaba, en las condiciones que estaba el fundo, todas esas cosas.(41)

De hecho, don Heriberto expresó su orgullo pro-

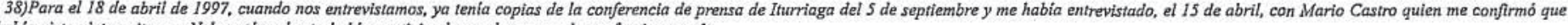
habia visto vietnamitas en Nehuentúe y hasta habia participado en el proceso de confeccionar más. 39) Entrevista con don Heriberto Aillo, Temuco, 18 abril 1997.

40) Ibidem.

41) lbidem.
} 
fundo por lo que habían sido capaces de hacer en Rucalán, cuánto habían mejorado la propiedad y cuánto habían producido. Esta prosperidad sería interrumpida, por supuesto, por la operación militar de Nehuentúe y la represión todavía más fuerte que se desató con el golpe del 11 de septiembre. Aunque don Heriberto logró escaparse en agosto, ya para el 18 de septiembre decidió entregarse porque los militares estaban presionando fuertemente a su familia. Inmediatamente lo empezaron a interrogar acerca del asentamiento Arnoldo Ríos.

De todas las cosas que me preguntaban es qué es lo que he hecho, en qué condiciones estaba, qué es lo que era yo en el asentamiento. Y bueno, yo en ese tiempo había salido elegido como presidente de agricultura...y trabajaba ahí. Entonces les dije, yo soy presidente en el asentamiento de agricultura, nada más. Y ellos me acusaron, justo me acusaron de que yo era presidente de la pérdida de la revolución...me mostraron todas las cosas y yo les dije que nosotros no hacíamos nada, nunca he pretendido hacer nada. todo.\}

$\{\mathrm{P}:$ Ud. negó todo y siguió ciertamente negando

Sí, y me preguntaron por mis compañeros, qué es lo que hacían y lo mismo de Ricardo Mora, que era el más asusta'o de todos. Les dije Ricardo Mora es una simple persona al igual que yo, no tenemos nada de que seamos personas tan merecíos para hacer cosas que no corresponden. El es un trabajador igual como nosotros, que cultiva la tierra, que por eso hemos progresado y por eso tenimos lo que tenimos. Nosotros en ese tiempo, no se si sabe que donde nosotros estuvimos, ese fue el mejor asentamiento, porque sabimos que de todos los asentamientos que hubieron antes del fina'o Allende, en el tiempo de Frei, en todo sentío, en crianza de cerdos, en crianza de ganao, ganadería y en crianza no se en todo lo que criaron y en siembra.(42)

Aún negando todo y protegiendo a sus amigos y compañeros, don Heriberto demostró su orgullo sobre lo que habían logrado. Su orgullo estaba íntimamente ligado a un sentido de justificación y legitimación, de que había sido legítimo y correcto tomar Rucalán porque posteriormente los asentados habían demostrado, mediante su árdua labor, que merecían el apoyo brindado por el gobierno popular. También sentía orgullo de haberse quedado callado, de no haber dicho nada que pudiera incriminarlo a él o a sus amigos. También por eso, sabiendo personalmente lo difícil que había sido callarse, es que don Heriberto expresó su enojo con las personas que no lograron hacer lo mismo. Un joven de Ailío, de menos de dieciocho años, no logró mantenerse callado al ser torturado durante la operación de Nehuentúe.

Ese estaba en la comunidad, ahí estaba establecido en la comunidad, se entusiasmó, se metió también al movimiento y quiso participar, quiso apoyar, ayudar. Era un niño joven, entonces como un niño joven fue débil, él entregó al resto de las personas. Si nosotros decimos no podimos entregar a otro, si realmente estaba, iba a servir. Entonces él entregó a gente que verdaderamente estaba involucrada en cosas graves, que es gente militar, entonces a nosotros no nos gustó esas cosas.(43)

Según lo que recuerda uno de los militantes del MIR que pasó tiempo en la zona, la marca del arresto y la tortura resulta indeleble. Este mismo militante, quien me habló bajo condición de anonimidad, me contó que había sufrido dos execuciones falsas y numerosos golpes, incluyendo golpes con piedras sobre sus testículos. Está convencido que la única razón que sigue vivo es porque Heriberto Ailío y los otros prisioneros tomados en Nehuentúe se quedaron callados, lo mismo que él. Insistió que el MIR fué la única organización motivada por la justicia para los mapuches. Quizá lo que se hizo fue utópico, inocente, excesivamente idealista; pero no se hizo maliciosamente y algunas cosas sí se lograron. La gente era tan pobre, recordó; la organización tuvo que enfrentarse a tantos desafios. A veces los que venían de fuera no aceptaban comer lo que se ofrecía, porque se daban cuenta que le estaban sacando la comida de la boca a los campesinos.(44)

Cuando le pregunté a don Heriberto acerca de la estrategia de alianza de clases del MIR, sin embargo, y qué efecto había tenido sobre los mapuches, su opinión fué diferente. «Claro, eso era una lucha de clases», confirmó, nosotros marcábamos todo, entre wingka y mapuche. Fué para tomar fuerza, pero en el fondo después fuimos los culpables nosotros, nosotros fuimos los 
terroristas más culpables nosotros, nosotros fuimos los terroristas más grandes. Y claro, el wingka también fue un terrorista más grande, pero como mapuche nosotros nos íbamos más fuerte sería, porque resistimos más.

Eso fue una lección que nosotros hemos aprendío, para no involucrar mucho al wingka, porque en esos momentos también, bueno que habían wingkas que estaban comprometidos, bastante comprometidos y con el golpe los desaparecieron y eso no fue bueno, fué un dolor que a nosotros...no correspondía. La lucha debíamos darla nosotros el pueblo indígena, y como a nosotros no se nos entregó la educación para poder darnos cuenta de lo que estaba pasando, incluso algunos mapuches se daban cuenta de lo que estaba pasando, pero no podían hacer nada porque no tenían la educación que corresponde. Entonces eso es lo que nos lleva...a que nosotros también emprendamos nuestro vuelo y luchemos por las propias fuerzas de nosotros, las comunidades indígenas. Bueno, ahí hay que ver también que hay wingkas porque resulta que se habla de comunidad indígena, pero por ejemplo en la comunidad Ailío cuando vino el reconocimiento a la comunidad, se logró reconocer los wingkas que estaban necesitados de tierra.(45)

Al terminar finalmente mi reconstrucción sistemática y terca de la operación de Nehuentúe, había entrevistado a ocho personas, leído las versiones de ocho publicaciones periodísticas y rearmado documentos en el archivo parcialmente destruído de la Intendencia en Temuco. Entre las varias dificultades, incluyendo de parte de algunos de mis entrevistados el temor de revivir viejas y dolorosas memorias, llegué a dudar si era acertada o viable una búsqueda enfocada solamente en la «verdad». Al enfrentarme a las negativas militares sobre los abusos de Nehuentúe la búsqueda de la verdad, y por tanto el desmentir las negativas de la dictadura, obviamente era una respuesta apropiada. También fué necesaria una estrategia enfocada en la verdad al enfrentarme a las negativas campesinas sobre la existencia de armamento en el sector reformado. Pero al igual que en el caso de Duhalde, una parte importante de esta historia yacía en las mismas capas de evasivas, mentiras y verdades parciales que con el pasar de los años se habían acumulado sobre los hechos de Nehuentúe. Como en los anillos que se dibujan en la corteza de un anciano árbol, en estas capas está grabada la historia de lo ya ocurrido, de las penas y hechos que motivan a la gente a recordar y olvidar de cierta forma. En las capas se dibujan también penas y traiciones, justificaciones personales y políticas, y la necesidad de seguir penando un sueño ya fracturado de justicia social.

Quizá en esas penas, traiciones y justificaciones encontremos otro motivo, más allá de la ya conocida invención militar de un baile ensangrentado de falsa justificación, que nos ayude a explicar porqué ambos lados participaron en la creación de un guión común que dejaba a los campesinos mapuches solamente dos papeles, o santo o demonio. Si el debate se mantiene a ese nivel los lados antagónicos también se mantienen limpiecitos: todos los izquierdistas, upelientos y populares de un lado; los militares y sus aliados del otro. Escarbar más profundo, como constaté por el camino, duele mucho más. Los restos sepultados más abajo 1legan a quemar los ojos: una utópica alianza clasista traicionada y fracturada; algunos militantes que informaron sobre otros o cambiaron de lado al ser presionados; algunos sobrevivientes que todavía temen salir del anonimato; unos pocos individuos todavía alimentando pequeños y harapientos deseos de igualdad e insistiendo que no todo habría sido en vano. Pensado así, no es tan importante saber exactamente cuántos rifles, escopetas, pistolas o vietnamitas tenía el MIR de la costa, o quién sería el dueño de las armas en la foto de El Diario Austral. La pregunta que sigue circulando a escondidas por el campo, y que se escurre entre mis manos cada vez que la intento agarrar, es si todavía será posible hacer nuestro ese sueño común, esa visión de un futuro más justo que soldados y helicópteros intentaron hacer trizas en esa mañana invernal de agosto de 1973.

Conclusiones: testimonio y etnografia en una época neoliberal

Como etnógrafa, historiadora y escribana testimonial trabajando en Chile después que se despejó el «taco» de solidaridad creado por la transición, mis tareas se dividieron, más o menos en partes iguales, entre ser la arqueóloga de historias y discursos sepultados por el tiempo y el sufrimiento; retejer las narrativas deshilachadas por la desinformación militar y las divi- 
siones políticas; penar sueños rotos y solidaridades perdidas; y servir de interlocutora de reflecciones acerca de pérdidas pasadas y posibilidades futuras. Como dice Mintz acerca de don Taso Zayas, mi propósito en este trabajo no es provocar ni lástima ni pena, pues estos sentimientos tergiversan el sentido de las luchas y las reflecciones que he logrado recolectar y preservar. El sentido de estas experiencias humanas es claramente multifacético, y va mucho más allá de lo que sugiere Gugelberger cuando concluye que «al final tenemos solamente el 'duelo', 'travail du deuil' como lo llamaría Jacques Derrida».(46)

En mi trabajo con Isolde Reuque, soy su testigo y secretaria mientras ella toma inventario de sus veinticinco años de activismo político, primero en el movimiento de derechos humanos después del golpe, luego como fundadora de los Centros Culturales Mapuches y del movimiento indígena mapuche de los 70 s y 80 s. Nuestras conversaciones le han ayudado a evaluar la relación contradictoria que existe entre la política partidaria y el movimiento étnico, entre la unidad étnica y la política feminista. Tanto sus reflecciones sobre su vida y su tiempo, sus triunfos y sus derrotas como dirigente indígena, como su compromiso poético y apasionado con la reconstrucción y preservación de la identidad étnica de su comunidad y su pueblo, nos inspiran no solamente a enfrentarnos a las recientes derrotas de los movimientos populares, sino que también a pensar más allá de las derrotas hacia un futuro nuevo y diferente.

Entre los muchos temas que tratamos en nuestras conversaciones, Isolde me habló de una depresión profunda que había vivido a mediados de los 80 s, cuando la organización mapuche que ella había ayudado a fundar pasó a manos de activistas mapuches del Partido Comunista. La consiguiente división política expulsó de la organización a las comunidades mapuches menos radicales y ella, con algunos otros dirigentes, también se salieron. Fué solamente después de un viaje a Nuevo México, donde conoció a una abuela Hopi que había sido activista toda su vida, que Isolde empezó a sobreponerse. «Yo creo que fué un momento emotivo, lleno de sentimiento, lleno de fuerza y también de dolor», me dijo. ban al borde de la desesperación en pensar que no hay nada más que se pueda hacer. Ella tenía el problema del basural atómico, y sentía que nadie la escuchaba. Que ya ni los mismos indígenas la apoyaban, porque estaban cansados de luchar...Y yo por otro lado frustrada porque la organización acá, el movimiento único, el movimiento más hermoso que yo había soñado, se había dividido. Yo lloraba, añoraba a ese movimiento que yo siempre decía debería ser apartidario—no en el sentido de que no pudiesen haber integrantes de los distintos partidos al interior del movimiento, sino que el movimiento no debía abanderizarse con uno solo de ellos. A lo mejor no fuí entendida; a lo mejor mi inmadurez política hacía que el lenguaje no fuera el apropiado. Es posible, pero yo estaba desesperada. Y esta hermana hopi estaba tan desesperada que al recibir mi visita, $\mathrm{mi}$ apoyo, mi fuerza, ella me daba más a mi, que yo a ella, por los setenta y tantos años que ella tenía. Y yo era una joven, y decía yo no me puedo desesperar, soy joven todavía, me falta mucho para llegar a los cuarenta y porqué entonces me desespero, si esta mujer que va llegar a los ochenta, que me dobla en edad, dice que todavía hay mucho por hacer.(47)

Este encuentro con otra dirigente indígena, marcado por el obsequio de un anillo de turquesa que Isolde todavía lleva en su dedo, representó para ella la necesidad de ver más allá de las derrotas presentes, hacia el pasado y el futuro, y de hacerse un eslabón en la cadena de luchas que ni empieza ni terminará en ella. Sus desilusiones en el movimiento mapuche catalizaron sus esfuerzos de ver más allá del proceso inmediato, y de construirse políticamente como una terca optimista. Hasta el día de hoy Isolde encuentra en sus experiencias iniciales organizando el movimiento mapuche las lecciones más grandes, y ve en las comunidades y tradiciones de su pueblo la fuente más profunda de sabiduría, no por alguna noción romántica de pureza ancestral, sino justamente por la capacidad de sobrevivir a pesar de enfrentarse a condiciones abrumadoramente negativas. «Lo más lindo que yo guardo en mi,» me dijo un día, son los viajes a las comunidades mapuches, a las comunidades de Chiloé, a las comunidades cercanas a los ríos, a los lagos. Son para mi paisajes especiales, donde yo me encuentro con Ngechen, donde yo puedo co-

Ver cómo dos mujeres que, siendo líderes, esta- 
municarme directamente con ese ser superior; donde yo encuentro un no sé qué y puedo llorar, puedo reír, puedo cantar, pueden brotar mis versos, poesías; puedo soñar y puedo envolverme en la realidad, a la vez. Yo creo que hay mucho de ese viento que sopla en cada uno de los paisajes. Donde más he podido disfrutar de ese encuentro con ese ser superior, ha sido en los lugares más apartados, en los lugares más contaminados, en los lugares donde alguien dice, ya no se puede hacer nada más. Ahi uno encuentra algo que te habla, que te dice. Una flor que renace entre tanta mugre, te dice que hay un momento de esperanza; y que el amor a la tierra, a la naturaleza, a la gente está cada día abierto al mundo, a las personas, a todos nosotros.(48)

Con seguridad en el caso de Isolde Reuque, Gugelberger estaría equivocado cuando asevera que «las personas subalternas no podrán escribir, pero sí pueden actuar».(49) Las personas subalternas como Isolde Reuque escriben, hablan y luchan. Refleccionan y crecen, impulsadas por los contratiempos y desilusiones del presente; se adaptan y reconstruyen mirando hacia el futuro. Si logramos escuchar y estar presentes después de que el «taco» de solidaridad se desplaza a otra parte, encontramos que nos queda mucho que aprender y discutir, mucho que procesar y debatir. Fué con la mirada puesta en estas conversaciones, presentes y futuras, que Isolde y yo acordamos titular su testimonio, «Una flor que renace».

A mi informe final sobre la comunidad de Ailío le puse el título «La sangre del copihue». A la gente de Gorbea les gustó, en parte porque contenía tantos significados. Se me había ocurrido por primera vez cuando en marzo de 1997, en medio del nuevo predio en Gorbea recién comprado con ayuda del gobierno, las familias de Ailío habían encontrado un pedazo de bosque nativo con los copihues rojos en flor. Pero al pensarlo más también me llamó la atención que, siendo el copihue la flor nacional chilena, referirme a la sangre de un copihue rojo representaba en forma escueta y precisa, el sufrimiento histórico del pueblo mapuche en su relación con el estado chileno. Específicamente en el caso de la comunidad de Ailío, representaba también lo que habían sufrido bajo la dictatura militar. En una carta reciente que recibí de don Heriberto Ailío y don Chami
Garrido, en representación de la comunidad en Gorbea, me hablaron de su deseo de darme nuevamente la bienvenida, a «la sangre del copihue».

También en el caso de Ailío soy testigo y secretaria de un proceso de luto, que mi trabajo quizá ha ayudado a canalizar: las utopías han fallado, los vecinos han peleado entre si. Las heridas son profundas y duraderas y a veces pienso que nunca van a cicatrizar por completo. Pero al igual que Isolde Reuque, los dirigentes de Ailío siguen buscando e incorporando las lecciones del pasado. En este contexto, las heridas empiezan a cicatrizar con la toma en posesión y el trabajo de la nueva tierra, quizá logrando remendar las relaciones con la parte de Ailío que se quedó en Tranapuente mediante el intercambio de productos agrícolas costeros y cordilleranos. Sanarse las heridas también ha significado reclamar una identidad mapuche que, mediante la reconstrucción de la comunidad, ha incorporado a wingkas pobres, como don Chami, que saben identificarse con el quehacer comunal.

Si me dan permiso, pienso seguir participando en las vidas presentes y futuras de la familia Reuque Paillalef y la comunidad de Ailío; y estoy segura que todos seguiremos escribiendo, conversando, luchando y actuando. Por un lado, el activismo político de Isolde y su estatura como dirigente le facilitan su capacidad de narración y le dan a su testimonio una relevancia potencialmente internacional. Su posición pública de intelectual hace de nuestra relación una colaboración más horizontal, aún cuando nos dividen las desigualdades de poder creadas por el centralismo político chileno, las herencias coloniales americanas, y la exclusividad de las academias en nuestros dos países. Sin embargo no me es difícil imaginar nuestra común participación en conferencias nacionales e internacionales, ¿quizá hasta una gira de promoción del libro una vez que salga publicado? Espero que el diálogo ya establecido entre nosotras siga prosperando; creo que será posible si logramos enfrentarnos a los nuevos desafios que se crearán en las futuras etapas de nuestra amistad.

Por otro lado creo que mi conección con la comunidad de Ailío seguirá siendo más completamente una relación de mediación y narración. Don Heriberto 
y sus hermanos doña Eduardina y don Robustiano son todos intelectuales locales y dirigentes de gran complejidad y capacidad reflexiva, pero no tienen ni la educación formal ni la estatura política regional para tener acceso a los foros en los cuales Isolde se siente cómoda. Con la comunidad de Ailío quisiera continuar nuestras discusiones de la historia de la comunidad, y pienso seguir ayudando, en lo posible, a encontrar fuentes de financiamiento para los proyectos locales. Me gustaría que colaboráramos en seminarios y proyectos sobre el desarrollo sustentable y los derechos humanos, y cuando logremos publicar la historia de la comunidad será necesario organizar presentaciones del libro en Temuco y Santiago a las cuales espero vendrán delegaciones de Gorbea y Tranapuente.(50)

Son muchas, sutiles y complejas las voces, historias y luchas que he tenido el privilegio de escuchar y registrar en la región de Temuco, pero estoy conciente que son una minúscula parte de lo que podríamos recuperar haciendo etnografía sistemática en esta época neoliberal. Como secretarios y etnógrafos postmodernos, espero que podamos incorporar estas voces, historias y luchas a un tejido social y conceptual más grande que nos ayude a dar sentido a las vidas que todos debemos vivir en esta época postrevolucionaria. Parte de este trabajo de tejer será, sin duda, un trabajo de luto; si no reconocemos las pérdidas sufridas y el dolor experimentado será imposible llegar con éxito a la próxima etapa. Pero al mismo tiempo, como ya me han enseñado Isolde Reuque y la comunidad de Ailío, la derrota de las opciones revolucionarias no ha roto la cadena entre el pasado y el futuro representada y reproducida por las luchas sociales contemporáneas. Isolde aprendió de su encuentro con la abuela hopi, su hermana activista, que la terquedad de la esperanza humana no tiene edad. Por un lado, nuestro trabajo en escuchar, registrar, comprender y debatir estas experiencias de lucha nos sugiere que el trabajo de luto es esencial a cualquier esfuerzo de pensar un futuro que merece el nombre. Por otro lado, sin embargo, el mismo proceso nos hace claro que la búsqueda terca y contínua de una justicia social nos lleva, inmediata y necesariamente, más alla de un atascamiento melodramático en el duelo como estado perpetuo.

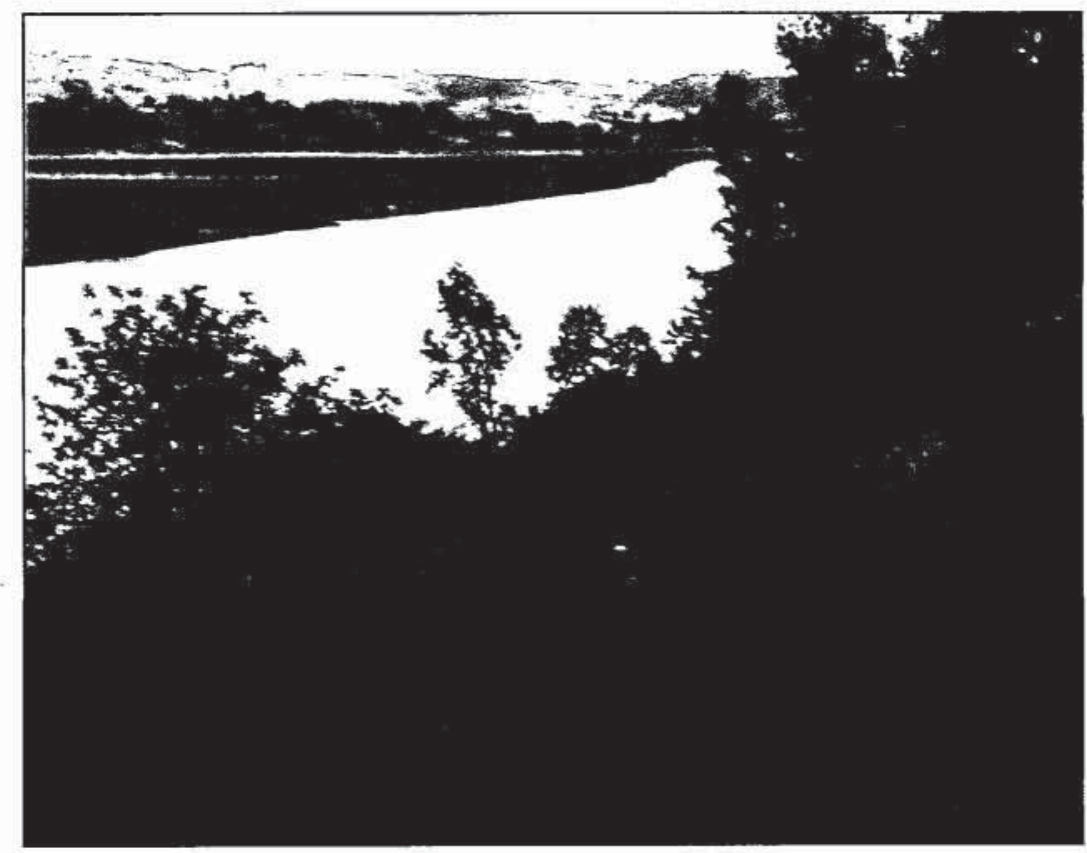

Sector Comunidad Ailio, foto de Bárbara Bustos - CES

50)Quizá esté demás anotar que las regalias de cualquier estudio de la comunidad deberán ser propiedad de la comunidad, cryá utilización deberia decidirse en forma colectiva. 